A CASE STUDY OF THE NATIONAL ENERGY BOARD DECISION: ENBRIDGE LINE 9B REVERSAL AND LINE 9 CAPACITY EXPANSION PROJECT

By

Heren $\mathrm{Wu}$

M.A., China Academy of Art, 2004

\author{
A Major Research Paper \\ presented to Ryerson University
}

in partial fulfillment of the requirements for the degree of

Master of Planning

in

Urban Development

Toronto, Ontario, Canada, 2014

(C) Heren Wu 2014 
Author's Declaration

I hereby declare that I am the sole author of this major research paper. This is a true copy of the major research paper, including any required final revisions, as accepted by my examiners.

I authorize Ryerson University to lend this major research paper to other institutions or Individuals for the purpose of scholarly research

I further authorize Ryerson University to reproduce this major research paper by photocopying or by other means, in total or in part, at the request of other institutions or individuals for the purpose of scholarly research.

I understand that my major research paper may be made electronically available to the public. 


\title{
A CASE STUDY OF THE NATIONAL ENERGY BOARD DECISION: ENBRIDGE LINE 9B REVERSAL AND LINE 9 CAPACITY EXPANSION PROJECT
}

(C) Heren $\mathrm{Wu}, 2014$

Master of Planning

in

Urban Development

Ryerson University

\begin{abstract}
This major research paper probed the recent controversy about the decision by The National Energy Board (NEB) to approve the Enbridge LINE 9 project. It examined the decision-making process using the in-depth-case-study analysis method. The research questioned the grounds this decision of the NEB was based on, whether this decisionmaking was science-based, and if its Environmental Assessment component adequately addressed the risk to the environment and affected communities. The investigation was based on the evidence that has been documented in the hundreds of hearing transcripts, filings, written evidence, regulations, reports, and other source of information such as invernors' websites and newspapers. Using a conflict-centered, retrospective narrative approach, the paper revealed the true nature of this decision-making process. Its flaws and defects were identified and deeper examinations of the relationships among the principal actors were revealed.
\end{abstract}

Key words: environmental decision-making process; science-based factors, interest groups 


\section{Acknowledgements}

The topic of this research was originated from a book that was recommended to me by Dr. Pushchak in his Planning Theory class. It was Rationality and Power-Democracy in practice by Flyvbjerg, 1998. I was captivated by the Flyvbjerg's fascinating story about the relations between the planning decision-making process and power relationships and Dr. Pushchak's humor and wisdom in his class at the same time. Without encouragement and supervision from Dr. Pushchak, this research would be impossible. I would like to thank Dr. Pushchak deeply and sincerely. I also would like to thank deeply Dr. De Sousa, who took time to review my paper as a second reader. 


\section{Table of Contents}

LIST OF TABLES ................................................................................................................ VI

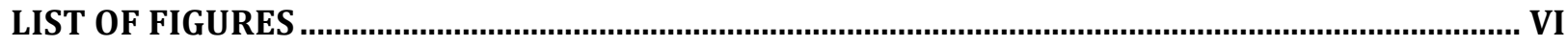

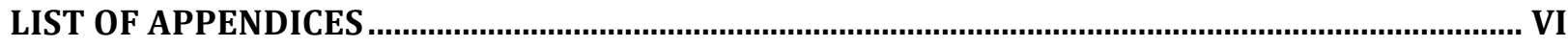

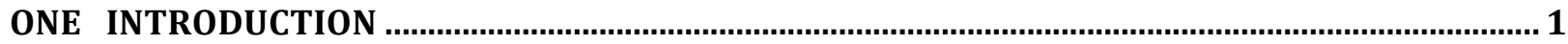

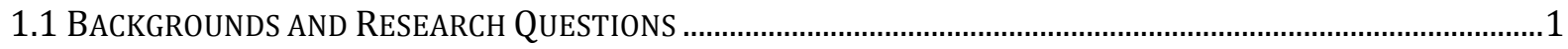

1.2 LITERATURE REVIEW...................................................................................................................................

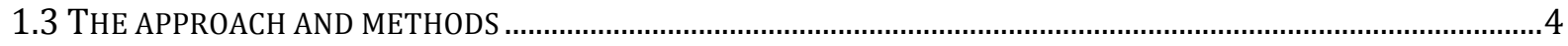

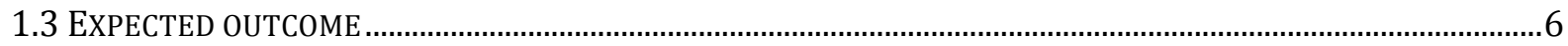

TWO TIMELINE AND CONTEXT ……...................................................................................

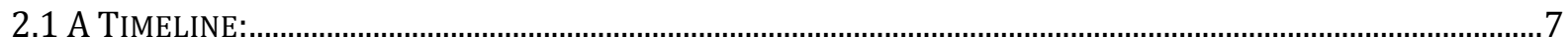

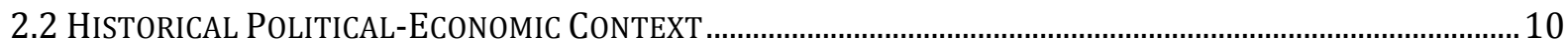

2.2.1 Oil crisis and the National Energy Program (NEP) ……................................................................10

2.2.2 The Free Trade Agreement (1989) and the pro-market energy policy shift ................................11

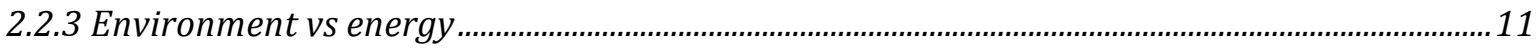

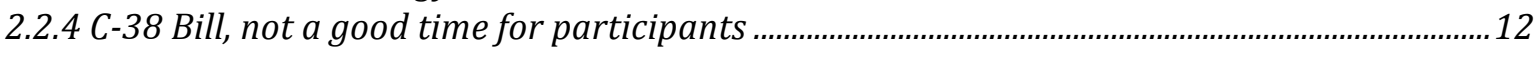

THREE MAIN ACTORS .......................................................................................................14

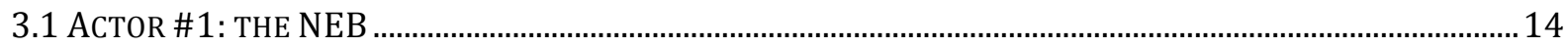

3.1.1 Who are members of the NEB? .......................................................................................................14

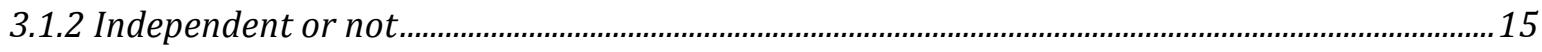

3.1.3 Functionality confusion 1: a facilitator or a regulator?................................................................18

3.1.4 Functionality confusion 2: a judge and a Third Party Certifying Authority ...............................19

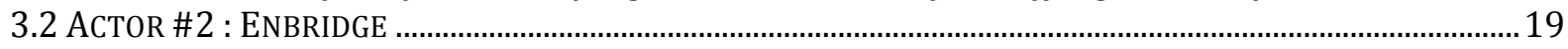

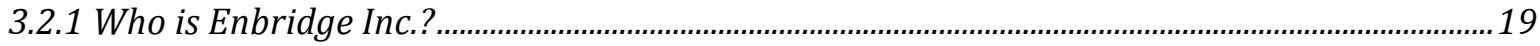

3.2.2 An energy transport giant t...............................................................................................................19

3.2.3 A spider web pipeline and spider web social connections............................................................21

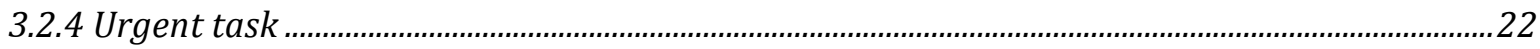

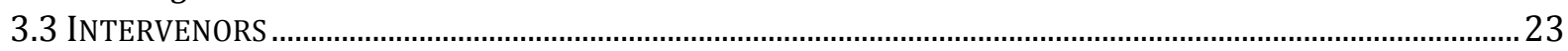

3.3.1 Who are the intervenors? ...................................................................................................................23

3.3.2 Win, Not on the Majority Side.................................................................................................................24

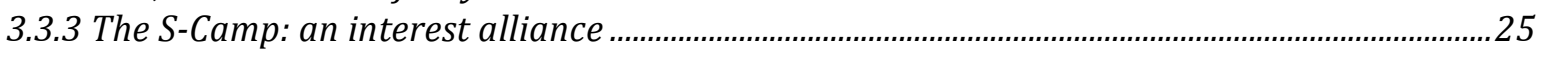

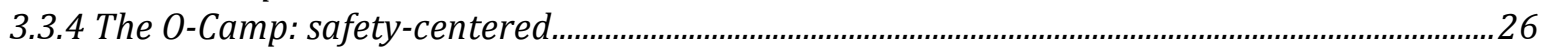

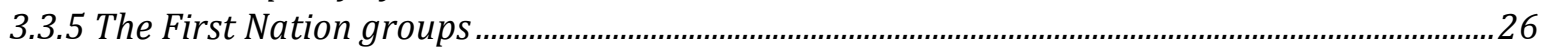

3.3.6 The Government intervenors ...............................................................................................................27

3.3.7 Environmental and citizen groups, limited resources ....................................................................28

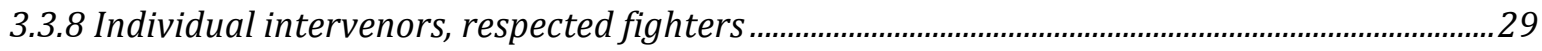

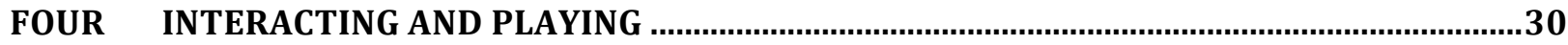

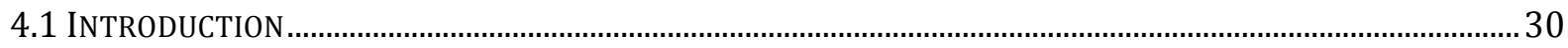

4.2 THE SCOPE BATTLE...............................................................................................................................

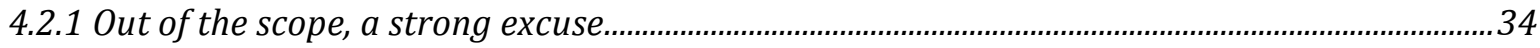

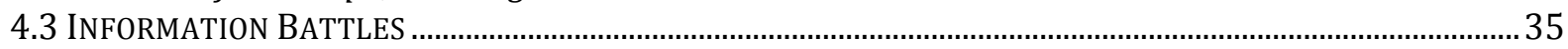

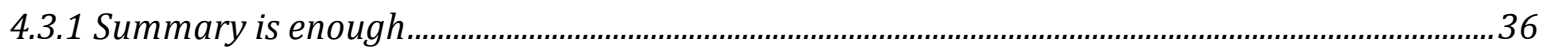

4.3.2 Is an information request a fishing expedition? .................................................................................37

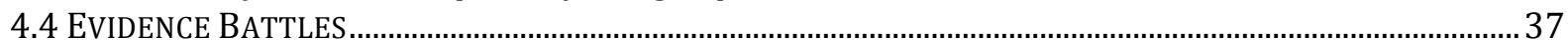

4.4.1 The attacks of the Goodman Group's analysis and the Accufacts Report .....................................38

4.4.2 Evidence battles outside the hearing ..............................................................................................39 


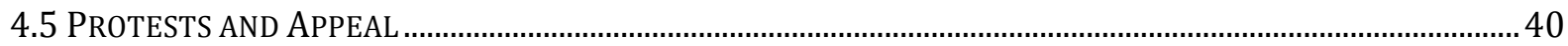

4.6 IS THE PUBLIC PARTICIPATION A “MERE LIP SERVICE”? .......................................................................... 40

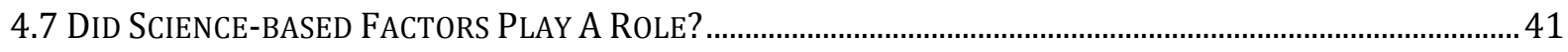

4.7.1 No Environmental and Socio-economic Assessment (ESA) needed ............................................42

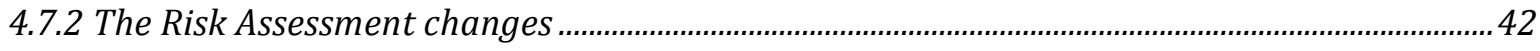

4.7.3 Future tense, the updated Pipeline Engineering Assessment .................................................... 44

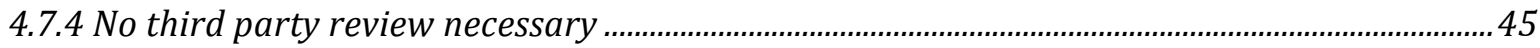

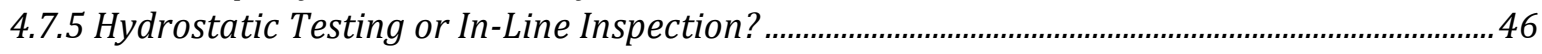

FIVE KEY FACTORS

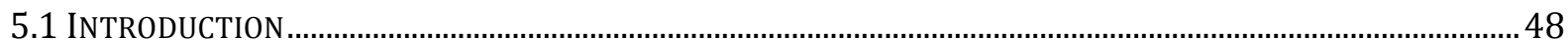

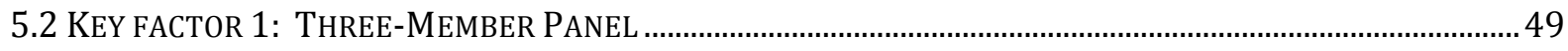

5.3 KEY FACTOR 2: INFORMATION TRANSPARENCY ……........................................................................ 52

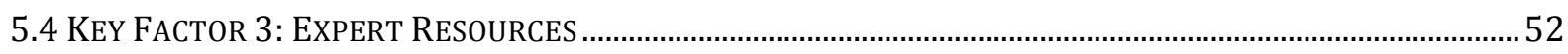

5.5 Key FACTOR 4: Tighter COALITIONS CREATE POWER...............................................................................54

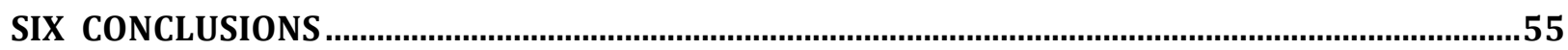

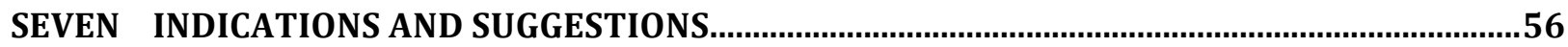

7.1 INDICATION 1: IT WERE INTERESTS THAT MOTIVATED THE RATIONALIZATION …........................................56

7.2 INDICATION 2: A BETTER DECISION-MAKING FORMAT AND A TRUE THIRD PARTY AUTHORITY SOLUTION.. 57

7.3 INDICATION 3: SCIENCE-BASED FACTORS AND EMPOWERING EXPERT COMMUNITIES..................................58

7.4 INDICATION 4: THE CURE FOR THE DILEMMA IN THE PUBLIC INTEREST LIES ALSO IN THE TRUTHFULNESS OF

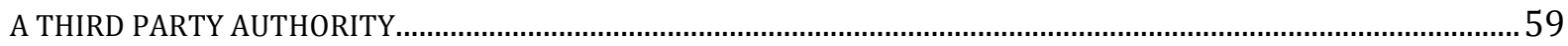

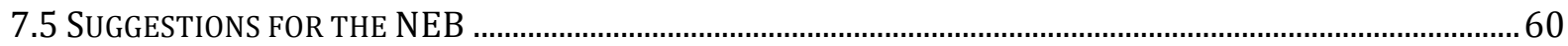

\section{List of Tables}

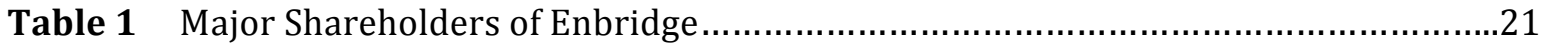

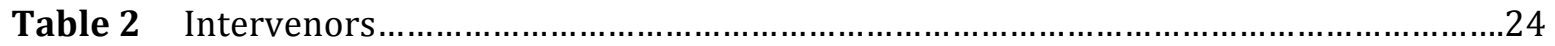

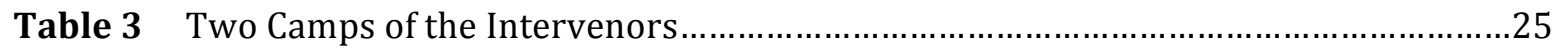

\section{List of Figures}

Figure 1 the Enbridge complex liquids pipeline systems

\section{List of Appendices}

Appendix 1 Main Actors in the Line 9 Project Proceeding................................................. 61

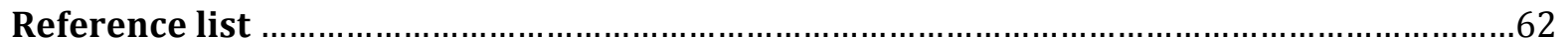




\section{ONE Introduction}

\subsection{Backgrounds and Research Questions}

The recent decision by the National Energy Board (NEB) to approve the Enbridge Line 9B reversal and Line 9 capacity expansion project has immediately raised many criticisms and protests. The Toronto Star expressed the critics' worries in the account below ("Make pipeline even safer," 2014, March 9, A10):

“Connecting Sarnia and Montreal, Line 9 traverses Ontario's urban heartland, crossing every major river in the GTA, passing through north Toronto, and coming distressingly close to the Finch subway station. Under these circumstances, the impact of a major spill on communities and the environment could be devastating."

"The 38-year-old line may have hidden weak spots that could give way under the pressure of this increased flow. Making fears worse, product being transported from western oilfields to refineries in Quebec could include diluted bitumen from Alberta's oil sands and even volatile crude from the Bakken region of North Dakota."

The most important aspects of the criticisms focus on how the National Energy Board failed to take advice from municipalities and Ontario's Ministry of Energy to impose "reasonable" conditions, which include performing a hydrostatic test and requiring Enbridge to increase insurance coverage for liabilities ("Make pipeline even safer," 2014, Mar 9, A10).

In light of the controversy, this major research paper will probe the decision-making process of the National Energy Board for the Enbridge LINE 9B reversal and Line 9 capacity expansion project. The research questions included: (1) what grounds was the 
decision based on, (2) was decision-making science-based, and (3) did the Environmental Assessment component adequately address the risk to the environment and affected communities?

\subsection{Literature Review}

Yosie (2000, p. 216) points out that science-based decision-making is "at a series of strategic crossroads." These "crossroads" include the changing approaches to "managing scientific research relevant to public policymaking"; seeking alternative models of environmental decision-making to those that "limit the application of scientific information and challenge scientists' ability to effectively participate in and shape the outcome of public health and environmental decisions"; and the changing expectations of what science can and should do "in evaluations of public health and safety and environmental quality" (Yosie, 2000, p. 216). Those expected changes are understandable as public pressure mounts from seemingly never-ending environmental incidents and even catastrophes.

The literature indicates that in environmental decision-making practices, sciencebased and stakeholder-based decision-making approaches are at odds with each other and usually are not reconciled in reality (Yosie, 2000). Some research has discovered that, in practice, socio-economic criteria are often considered as important as the availability of "robust scientific data and insights" (Younger, Coulton, \& Froggatt, 2005; p137). What lies at the core of these decision-making processes is how science plays its role, and how experts exert their expertise. However, McGarity and Wagner point out the "accounts of 'bending' science-where research is manipulated to advance economic or ideological ends-are not only prevalent in the corridors of courts and legislatures, but also beginning 
to emerge from deep within the inner sanctum of science" (McGarity \& Wagner, 2008; 1 ). Moreover, much of the literature written about decision-making practices has revealed that even the most technical decisions can be affected by power interests (Fljvbjerg, 1998,Talor, Kim \& Gahbauer, 2009). Flyvbjerg's proposition indicates "rationality is context-dependent, the context often being power" and it will be "meaningless, or misleading...to operate with a concept of rationality in which power is absent" (Flyvbjerg, 1998; 227). This indicates that science-based decision-making is dependent upon its context. There are also some researchers who criticize this Foucaultian study by saying that "These flaws lead to very grave dangers in any attempt to develop a planning theory based on Foucault" (Stein \& Harper, 2003;125) and "a theoretical privileging of the vocabulary of power could blind us to other realities, by reinterpreting everything within a reductionistic metanarrative of power and power structures" (Stein \& Harper, 2003; 125).

There are a growing number of studies that are dedicated to the precautionary principle "first do no harm" in public health and environmental decision-making. The precautionary principle suggests that the absence of evidence of evidence of harm is not a justification for proceeding. Its advocates strive to have it "become a cornerstone for developing policies related to the environment and public health" (Goklany, 2001; 2), especially when decision makers are facing dilemmas. However, Goldstein (2001,p. 1358) pointed out "the precautionary principle is at times presented by its supporters as a rationale to stop doing scientific research on a subject." It is interesting to see how far this principle will go.

There is relatively very little literature that specifically focuses on decisions about oil pipelines. However, it is worth mentioning that some researchers have studied the 
assessment processes for major oil and gas pipeline projects in Canada. Van Hinte, Gunton and Day found that only three of fourteen best-practice criteria were met in the eight proposed major pipeline projects in Canada, and that "the most significant deficiencies are: lack of clear decision-making criteria and methods" (Van Hinte, Gunton, \& Day, 2007;123). Additionally, Hoberg, Rivers and Salomons have compared the dynamics of pipeline politics between Canada and the United States. They found that both sides had made prominent efforts to "exert political control over the regulatory process" (Hoberg, Rivers, \& Salomons, 2012; 21). In Canada, "the climate issue has essentially been taken off the agenda for the pipeline through the joint Review Panel's narrow scoping decision" (Hoberg, Rivers, \& Salomons, 2012; 23).

\subsection{The approach and methods}

This research used the in-depth case study method, combining the history-comparative and document-analysis methods to reveal the true nature of the decision-making process in a political-economic context. This research was approached in three steps. The first step was a literature review. The research built the analysis on the practical decision-making literature, and focused particularly on the research in science-based, planning and environmental decision-making. The second step was to conduct an in-depth case study analysis, which aimed to provide an analysis of this decision-making process in a historical context. This step was conducted in the following sequence: 1) the timeline of the project was provided in a political-economic context, 2) an analysis of the actors involved in the decision-making followed, 3) an analysis of the factors influencing the decision-making, was done and 4) an analysis of the interactions among those actors and how the roles of those science-based factors, especially probabilistic risk assessment, influenced the 
outcome. The last step was to summarize and analyze the findings, to present further inductive reasoning regarding science-based decision-making.

In this in-depth case study process, the paper used the historical-comparative method to put this decision-making timeline into a larger, historical, political-economic context. Thus, the history of this 38-year-old pipeline was found in the testimony of the changing, social, and political-economic context in which the current NEB's regulatory decisionmaking also became more understandable. The document analysis method also played an important role in the research. The paper tried to establish a review of what happened during the hearing proceedings (the process that determined the decision) in the past. The most accurate pieces of evidence were the hundreds of filing documents, transcript records, written arguments, and most important, the written expert evidence. What has been said, what evidence had been presented, and who presented it during this NEB decision-making process were the most significant facts that this paper relied on. Without interviews of intervenors, this research may lack insights of interview suspects retrospectively, but to keep a distance from those actors may also maintain a distance from their biases that are often shaped by their interests or ideologies. Except for the hundreds of Board orders, compliances, hearing transcripts, and written evidence that the research relied on, the paper also used many non-traditional sources, including hundreds of actors' websites, reports and interviews in the newspapers.

The research approach was a conflict-centered, retrospective narrative approach, thus the analysis of the main actors and their interactions was the centerpiece of the study. The paper used many in-text citations in order to bring readers back to this controversial 
hearing proceeding, to experience the different perspectives, to demonstrate the competing evidence.

\subsection{Expected outcome}

Decision making, especially risk-informed regulatory decision making, is always a crucial component in planning practice because the stakes in these decisions are very high in terms of social, economic and environmental impacts. In the Kalamazoo incident, Enbridge spilled 3.3 million litres of oil into the Kalamazoo River in Michigan, costing the company more than $\$ 1$ billion (Max Paris Environmental Unit, 2013, Sep 06). Based on the Enbridge 2009 Corporate Social Responsibility Report, there were "804 spills that released 161,475 barrels of hydrocarbons into the environment" throughout the company's history between 1990 and 2010 (Girard, 2010; 53). In terms of Enbridge's Line 9 operations specifically, CTV W5 uncovered 35 spills since 1976 (Burns-Pieper, 2014). All these incidents remind us of the consequences the decisions of the NEB can have. Evaluating one of the regulatory decision-making processes of the NEB will extend the literature on science-based, environmental decision-making.

The paper did not intend to present big decision-making remedies, but these kinds of excavations shine a light on aspects of the decision-making process that make us understand the problem and also may point to a direction for the solutions. 


\section{TWO Timeline and Context}

Any decision-making process cannot escape from a political and economic context and cannot be comprehended fully without it. This is especially true for oil pipelines. Pipeline 9 is only one piece of a big puzzle of the pipeline system in North America, but it still reflects the ever-changing structure of the global oil market and the strategic decisions between countries in North America regarding national energy security. At first, the paper will try to provide the timeline of the project in a political and economic context.

\subsection{A Timeline:}

The decision-making process of the NEB regarding the Enbridge Line 9B reversal and Line 9 capacity expansion Project (the Line 9 project) has been put into one chronology of the Line 9 history (NEB, 2014, Reasons for Decision OH-00202013).

\section{Chronology of the Line 9}

April 8, 1975

A 20 year agreement between the government of Canada and IPL to construct an extension oil pipeline from Sarnia to Montreal was signed.

June 4, 1976

Line 9 (the Montreal Extension) was opened with a throughput capacity slightly over 315,000 barrels per day(bpd)

February 25, 1977

An additional agreement between the government of Canada and IPL to provide an option for the government to purchase Line 9 was signed. 
June 4, 1996

May 1, 1997

December, 1997

1999

August 8, 2011

July 27, 2012

November 29, 2012

December 19, 2012

The Line 9 Project:

October 11, 2012
The agreement between the government of Canada and IPL was terminated and IPL would continue to own and operate Line 9

IPL applied to reverse the direction of flow in Line 9 in order to transport crude oil to major refineries in Ontario from Montreal at a capacity 240,000 bpd

The NEB Board approved the IPL Line 9 Reversal Project by Order X0-J1-34-97

The Line 9 Reversal Project is completed and opened Enbridge applied to the NEB to reverse a $194 \mathrm{~km}$ segment of Line 9A between the Sarnia Terminal and the North Westover Station in Ontario ( Line 9 Reversal Phase I Project)

The NEB Board approved the Line 9 Reversal Phase I Project through its Order XO-E101-010-2012

The NEB received a pre-application information filing regarding the reversal of Line 9B.

Enbridge filed the application for reversing the $639 \mathrm{~km}$ segment of Line 9 from North Westover, Ontario to Montreal, Quebec (Line 9 B) and increasing the annual capacity of the entire Line 9 from 240,000 bpd to about 300,000 bpd The Board determined that the application was adequately complete to proceed to assessment. 
February 19, 2013

February 19-21, 2013

April 3-9, 2013

April 4, 2013

April 19, 2013

May 22, 2013

August 2013

August 16, 2013

September 30, 2013

October 8-11, 2013

October 16-18, 2013
The Board issued the OH-002-2013 Hearing Order

Information sessions in Hamilton, Toronto and Montreal

Additional information sessions as requested by members of the public in Kingston, Rigaud, Ajax, and Longueil, were held The board provided the Application to Participate (ATP) form to interested persons and set a two week deadline for its submission

The deadline for submitting the completed ATP forms was reached

The Board released Procedural Update No.2 (the list of parties and the list of commenters permitted to participate in the proceeding)

The Line 9 Reversal Phase 1 Project was completed and opened The Board released Procedural Update No.3 (scheduling the oral final argument on 8 October 2013)

The Board released Procedural Update No.4 (providing parties with the order of appearances, a list of potential draft conditions, and an updated exhibit list)

Oral final arguments were held in Montreal, Quebec Oral final arguments were held in Toronto, Ontario 


\subsection{Historical Political-Economic Context}

"While all oil and gas pipelines perform similar physical functions, the institutions that surround them are stubbornly dissimilar from country to country" (Makholm, 2012, px)

\subsubsection{Oil crisis and the National Energy Program (NEP)}

The birth of Line 9 was the implementation of the national-energy-security strategy begun after the 1973 Oil Crisis, which was directly caused by the oil embargo imposed by the Organization of Arab Petroleum Exporting Countries (OAPEC). The concern over the vulnerability of eastern Canadian oil refineries, which depended heavily on overseas crude oil imports, led the government of Canada to enter into an agreement with Interprovincial Pipe Line, Ltd. (IPL), which was the initial name of Enbridge, to construct an extension from Sarnia to Montreal in order to transport crude oil from Alberta to eastern refineries. Through this 20 year agreement, the government of Canada guaranteed compensation for any loss that resulted from possible low throughputs. On February 25, 1977, an additional agreement provided an option for the Government of Canada to purchase Line 9 (NEB, 2014, Reasons for decision OH-002-2013).

Shocked by the 1973 embargo, the political-economic atmosphere in Canada for the crude oil market in the 70s was naturally dominated by policies leading to state interventions in and regulations of both intranational and international oil trades. However, "in 1981, the six largest oil companies in Canada [were] all foreign controlled (mostly by America)" and foreign owners controlled seventeen of the largest oil and gas companies in Canada by sales and in 1979 "had $71.7 \%$ of the total sales in the industry equaling over $\$ 6$ billion dollars (Canadian) and the eight Canadian controlled companies had $18.7 \%$ of total sales equaling just $\$ 1.6$ billion (Canadian)" (Getman, 1980; 162). Understandably, the introduction of the federal government's National Energy Program 
(NEP) in 1980 was designed to increase the share of Canadian ownership of the energy industry, to promote oil self-sufficiency by 1990 and to provide an equitable share of the profits from energy for all Canadians (Getman, 1980). However, Western Canadians, especially in Alberta, had a different idea and they regarded the NEP as one that discriminated against them, and the oil and gas industry regarded the NEP "as an unnecessary government intrusion into their business" (Nemeth, 1998; 87). With the help of oil market changes (falling price), those political and economic powers eventually disabled the further implementation of a state-control energy policy.

\subsubsection{The Free Trade Agreement (1989) and the pro-market energy policy shift}

It was the Mulroney majority conservative government (which won election in 1984) that started to realize the dramatic shift from the Trudeau Liberal state control policy to a pro-market energy policy. This naturally led to the Canada-U.S. Free Trade Agreement (FTA) 1989, which required that Americans did not need to pay more than Canadians for oil. On May 1, 1997, shortly after the government of Canada and IPL were both released from the agreement (On June 4, 1996), IPL applied to the NEB to reverse the direction of flow in Line 9 in order to transport crude oil to major refineries in Ontario from Montreal, mainly because importing crude oil was more cost effective for Eastern Canada in a more open market (NEB, 2014, Reasons for Decision OH-002-2013).

\subsubsection{Environment vs energy}

However, never-ending environmental incidents and disasters, the global warming issue and a new ideology shift to sustainable development have been challenging more and more those profit-centered traditional energy super powers. "The second recent historical point to be emphasized centres on the growing interactions between energy policy and 
environmental policy [...] with the political emergence of the environmental movement in the late 1960s, the linkages between energy and environment have intensified and have also become both more complex and more specific" (Doern, 2005; 10). Doern's arguments are especially strong regarding the Line 9 Project. The increasing number of intervenors in the pipeline approval process could also demonstrate this environmental awareness. Caron, the former Chair and CEO of the NEB, mentioned in a speech: "It wasn't that long ago when most people in Canada had no idea who we were. When we reviewed an application from Trans Mountain Pipeline for its Anchor Loop project in 2006, there were 8 intervenors. In our current review of the Trans Mountain Expansion Project, there are 400 intervenors" (Caron, "Reflections on 35 years", 2014). After the 1997 Kyoto Protocol, Prime Minister Chretien announced that Canada would ratify the Kyoto pact by the end of 2002, in addressing mounting environment political pressure both internationally and nationally (Doern, 2005). However, the Harper Conservative Government has been changing the direction of the dynamic between environment and energy toward an even more pro-energy development strategy, which followed the Bush government's alternative to Kyoto protocol policy. Harper even declared Canada "the emerging energy superpower" in a speech at London in 2006 (Blanchfiel, 2006, n.d.). In light of the economic crisis and uncertainty, the most recent C-38 Bill is the most effective indicator of the current political context.

\subsubsection{C-38 Bill, not a good time for participants}

Bill C-38 was introduced as the Jobs, Growth and Long-term Prosperity Act in 2012. In front of Parliament, Shelly Glover, Parliamentary Secretary to the Minister of Finance, said: "At times like these, Canadian families want their government and elected officials to 
stay focused on the economy, not on partisanship or procedural games. Canadians see the headlines about Greece and Spain... Canadians do not want economic uncertainty" (Parliament, Bill C-38 (historical), online, n.d.). The message from the majority conservative government was clear: It was time to focus on the economy and not 'procedural games'. The procedural change that the bill made to the NEB was mostly to reduce the chances of participation by environmental groups, which could postpone the decisions, and would impede development in the energy sector, which was regarded as hurting the economy.

The 2012 Federal Bill C-38 made the Line 9 hearing the first hearing in the NEB's history where members of the public needed to apply for permission to send a letter with comments. The 10-page form that a participant needed to fill out requested a resume and references. The implications of this procedure are profound for public participation especially for the environmentalists. Adam Scott from Environmental Defense (one of the Intervenors) called the change "undemocratic" (Paris, 2013). Recent environmental disasters in the U.S. and Canada would further intensify the tension between energy development and environmental protection. In this historic political-economy context, the story of the NEB decision-making process on the Line 9 Project began. 


\section{Three Main Actors}

The story will begin with an analysis of the actors involved in the decision-making process. It will start with NEB, followed by the applicant and intervenors.

\subsection{Actor \#1: the NEB}

Acting as a quasi-judicial tribunal, the members of the NEB act as judges to make decisions, therefore the NEB is the most important decisive actor in each applicant project. The Board has the power to choose who can participate in the hearing process and who cannot. It is up to the Board to decide which evidence can be weighed in the decision among competing claims. Therefore the NEB is the most crucial actor in this decisionmaking process.

\subsubsection{Who are members of the NEB?}

The NEB, according its website, "is an independent federal agency established in 1959 by the Parliament of Canada to regulate international and interprovincial aspects of the oil, gas and electric utility industries" (NEB, "Who we are", online, n.d.). The great pipeline debate in 1956, which was considered the catalyst for the failure of the liberal St. Laurent government, was the most important political event before the creation of the NEB. The creation of the NEB moved the hot parliamentary debate into a adversarial format among stakeholders inside an independent quasi-judicial tribunal (similar to a civil court). The NEB is "accountable to Parliament through the Minister of Natural Resources Canada" and the task of the NEB is to "regulate pipelines, energy development and trade in the Canadian public interest" (NEB, "Who we are”, online, n.d.). Its head office is located in Calgary, Alberta. There are currently 7 members and 6 temporary members assisted by approximately 400 employees and with a $\$ 60$ million annual budget ( $90 \%$ of its costs are 
recovered from the energy sector through levies) to operate as an independent federal quasi-judicial tribunal. Board Members (up to nine) can be appointed by the Governor General on the advice of the Committee of Council (NEB, "Who is the National Energy Board", online, n.d.). The Board decisions are final, except for export licenses and certificates for new facilities, which must get approved by Cabinet; however, those decisions are "generally subject to appeal only on grounds of law or jurisdiction" (NEB, "Who is the National Energy Board", online, n.d.).

\subsubsection{Independent or not}

In a presentation to the University of Toronto International Relations Society, Alison

Scott, a Board member, told the audience: "the Board is and has always been independent. We operate within the mandate set for us by Parliament but at arm's-length from government and free from political influence" (Scott, 2014, slide 2). However, NEB's claim to be 'independent' and 'free from political influence' is not the case according to Lucas. In his research, Lucas wrote that "elected governmental officials are said to be responsible to Parliament, and ultimately to their constituents for resource and environmental management decisions made under their auspices. In Canada and Great Britain where a majority party executive often tightly controls the legislature, this concept of ministerial responsibility is regarded as a hallowed constitutional safeguard" (Lucas, 1976; 75). Leaving the constitutional monarchy aspect apart, Canada is a parliamentary representative democracy, which is the context for any environmental decision-making. Any authoritative agency group with legitimate authority to make any environmental decision may claim its independence but actually is context-based, which means it is always subject to political influence. 
The NEB held its historical first hearing in 1960 in Ottawa, two months after the creation of the NEB. Gaetan Caron, NEB's former Chair and CEO, spoke at the 2014 Alberta Energy Regulator's Forum and reflected on his 35 years with the NEB. After showing an old picture of the first members of the NEB, he mentioned that "At the time, the Ottawa Journal wrote: "The power we have entrusted to this board is formidable. It must be both judge and prophet, a double wisdom which at times must seem a humbling duty." And this duty, he further assured, is "indeed humbling still today" (Caron, "Reflections on 35 years", 2014). The requests to execute this power are indeed intimidating, but the consequences of these environmental decisions are even more crucial to Canadians. The 'double wisdom' requirement for this job itself demonstrates the struggle in the swirl of many power interests.

Another way to sway this 'arms-length' agency by a majority government is through appointment of those Board members. Greg Rickford, the Federal Natural Resources Minister, just announced that Peter Watson, currently deputy minister for the Alberta premier's executive committee, has become the new boss of the NEB. However, Greenpeace campaigner Mike Hudema immediately expressed his disappointment: "If the Harper government was hoping to temper the growing criticism of flawed National Energy Board processes it is heading in the wrong direction with this appointment. Alberta is a very troubled regulatory jurisdiction, especially when it comes to pipelines, so choosing an insider from within its ranks doesn't bode well for the environment or communities across the country" (Mccarthy \& Gryderman, 2014, n.d.).

These kinds of controversies are not new for the NEB. In 1975, a similar question arose when Marshall Crowe, the boss of the NEB from 1973 to 1978, sat on the panel with 
two other members to hear arguments for competing applications to build pipelines to transport natural gas from the Artic to the US markets. As Crowe had been working for the Arctic Gas Pipeline Limited (Artic Gas), one of the competitors in the application, before he joined NEB, five of the intervenors objected to his participation at the opening of the hearing. Then, the NEB asked the Federal Court of Appeals if the Board could reject the objections from intervenors. The ruling of the Federal court of Appeals supported the NEB's request not to remove Mr. Crowe from the panel. However, the Supreme Court of Canada reversed the ruling of the Court of Appeals on the ground that the NEB, with a quasi-judicial nature, should apply the nemo judex rule to its proceeding (Jones, 1977). Nemo iudex in causa sua (or nemo iudex in sua causa) is the second principle of natural justice that no person can judge a case in which they have an interest. Jones (1977, p474) argues in his research on "attitudinal bias": "If the policy underlying the nemo judex rule is indeed the preservation of the public's confidence in the impartiality of adjudicative agencies, the likelihood of actual bias is irrelevant." Jones concluded: "greater awareness by the government of possible or perceived conflicts of interest would cause it to exercise greater care in appointing its various officers, particularly to quasi-judicial bodies" (Jones, 1977; 484). Unfortunately, this seems often the opposite in reality.

Besides the appointment of the new boss of the NEB, most the Board members have work experience in the energy private sector, which could give them an advantage in becoming a member and also the likelihood of 'attitudinal bias' at the same time. For example, the newly appointed vice-chair, Lyne Mercier, has worked at Gaz Metro for over 29 years and served 10 years in an executive position, according to the website of the NEB (Gaz Metro Inc., according to its website, is " $100 \%$ owned by Noverco, Inc., which in turn is 
owned by Trencap L.P. (61\%) and Enbridge Inc. (38.89\%)") (Gaz Metro, “Corporate Structure", online, n.d.). Mercier was the Chair in the panel hearing the Line 9 reversal project. Saying that justice (for the sake of public interest) has been done in any environmental decision-making process or by any policy is not enough, especially in the case of Canada with vast geo-economic differences across provinces and territories. As Jones' research conducted in the 1970s reminds us: “ justice must not only be done, [but] must manifestly be seen to be done" (Jones, 1977; 463).

\subsubsection{Functionality confusion 1: a facilitator or a regulator?}

There also were two functions embedded in the role of the NEB. Let's start with the first: regulation and partnership. Priddle served as Chair of the NEB from 1986 to 1997, and described the past history of regulation by the NEB from 1959 to 1998 as going "from persuasion to prescription and on to partnership" (Priddle, 1999, p.524). This partnership concept can be found on the current NEB website: the vision of the NEB as an "active, effective and knowledgeable partner in the responsible development of Canada's energy sector for the benefit of Canadians" (NEB, "Energy Information Program-What is the National Energy Board", online n.d.). This partnership between the NEB and Canada's energy sector is said here to be good for the Canadian public interest. However, Dave Core, director of federally regulated projects for the Regina-based Canadian Association of Energy and Pipeline Landowner Associations (CAEPLA), raised the question of how one partner can regulate another partner (Nikiforuk, 2011). Indeed, there is a natural conflict in the NEB's two roles of being a regulator of and a partner to Canada's energy sector, because a partner will put the prosperity of the sector first, but a regulator will put regulations first. Many times the two roles are in conflict. 


\subsubsection{Functionality confusion 2: a judge and a Third Party Certifying Authority}

The core responsibilities of the NEB are to review the technical and financial

feasibility, the environmental and socio-economic impact of the project, then further to audit and inspect the construction and operation of pipelines (NEB, Our Responsibilities, online, n.d.). This requires not only judgment by the NEB Members, but also expertise from the specialists at the NEB. The NEB claims that it also is a Third Party Certifying Authority, which can conduct the critical review of those science-based key factors, such as, in this case, the Pipeline Integrity Engineering Assessment that includes the Pipeline Risk Assessment. These double duties will not only easily cause confusion among intervenors (some intervenors had been inquiring about double responsibilities in this case) but also create distrust if the NEB cannot adequately show its capacity to analyze objectively and its neutrality toward intervenors and the public.

\subsection{Actor \#2 : Enbridge}

\subsubsection{Who is Enbridge Inc.?}

As the applicant of the Line 9 project, Enbridge is the second important actor to understand. For a long time, it has escaped wide spread public notice, but Enbridge "now finds itself the subject of intense media and public scrutiny as a result of a series of catastrophic pipeline ruptures and the controversial Northern Gateway Pipeline proposal" (Girard, 2012; 3).

\subsubsection{An energy transport giant}

Enbridge Inc. is a major energy transporter in North America and a natural gas distributor in Ontario, Quebec, New Brunswick and New York State. The company, incorporated in 1949, was initially known as the Interprovincial Pipe Line Company (IPL). After 61 years of operation, the Financial Post ranked Enbridge as the $21^{\text {st }}$ biggest 
company by revenue (2010) in Canada and its American Company, Enbridge Energy Partners, sat at the $309^{\text {th }}$ position of the Fortune 500 list in 2010. With approximately 25,420 kilometers of pipe, the company operates the largest petroleum pipeline system in the world and transports an average of 2.2 million barrels per day (bpd) of liquids and crude oil. It delivers 53 percent of Canadian oil into the American market, which accounts for 15 percent of total U.S. crude oil imports. Figure 1 shows the Enbridge complex liquids pipeline systems (Enbridge, 2013, liquid Pipelines map).

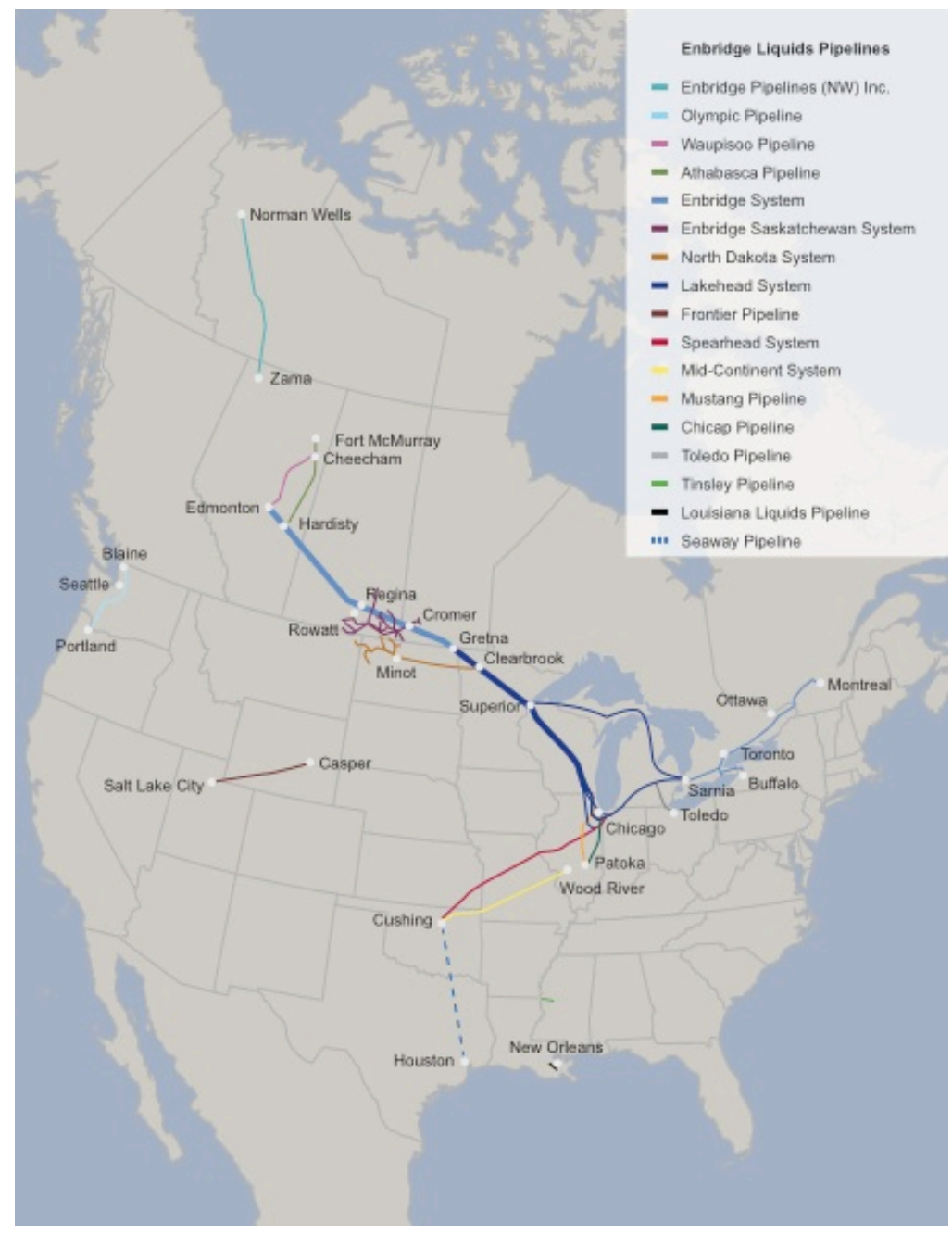

Line 9 is part of its Canadian Mainline system, which starts in Edmonton, Alberta and connects Enbridge's Lakehead System in America to Montreal, Quebec (Enbridge, 
"Liquids Pipelines", online, n.d.). The reverse of the flow on Line 9 will help to transport tar sands oil to Eastern Canada and United States (part of its Trailbreaker project) (Girard, 2012).

\subsubsection{A spider web pipeline and spider web social connections}

Along with its huge, long and complicated spider-web-like pipeline systems, Enbridge has very wide, deep and complicated spider-web-like social and political connections across North America. The unique nature of Enbridge's business involving long-distance energy transport and supply across vast and complicated social differences and geographic distances, requires strong and deep ties with all jurisdictions it has crossed. This is because "long-distance transport embodies a unique collection of problems in technology, finance and credit, property rights, public access, land use, and uncertainty" (Makholm, 2012; 7-8). According to Girard's (2012) research, Enbridge has built strong industry, financial, political, university and research connections in Canada through investment, partnership, lobbying, sponsorship and donation. If Enbridge is combined with its clients (all of the major oil, gas companies and refineries related to the tar sands, visible in the hearing of the Line 9 project), investors, shareholders, hired public relations firms, it can be seen as an extremely powerful network. Table 1 (Financial Times, "Business profileEnbridge Inc.-Institutional shareholders", online, n.d.) shows that Enbridge also has some very powerful shareholders including some of the major banks in Canada.

Table 1: Major Shareholders of Enbridge

\begin{tabular}{|l|c|c|}
\hline \multicolumn{1}{|c|}{ Holder } & Shares Held & Percentage of Shares held \\
\hline $\begin{array}{l}\text { Capital Research \& Management } \\
\text { Co. (World Investors) }\end{array}$ & $63.14 \mathrm{~m}$ & $7.56 \%$ \\
\hline
\end{tabular}




\begin{tabular}{|l|c|c|}
\hline RBC Global Asset Management, & $61.69 \mathrm{~m}$ & $7.39 \%$ \\
\hline TDc. & & \\
\hline The Caisse de depot et placement & $39.27 \mathrm{~m}$ & $4.70 \%$ \\
du Quebec & $31.90 \mathrm{~m}$ & $3.82 \%$ \\
\hline BMO Capital Markets (Canada) & & $2.44 \%$ \\
\hline
\end{tabular}

\subsubsection{Urgent task}

According to the Canadian Association of Petroleum Producers (CAPP, "Crude oil forecast”, 2014, p. i ) 2014 crude oil Forecast, Markets \& Transportation report, “Canadian oil production growth is driven by the oil sands, which is expected to grow 2.5 times from current production of 1.9 million b/d to 4.8 million b/d by 2030"; however, the transportation of those products will become "bottlenecked" if the proposed pipelines cannot be realized. The NEB report on the energy supply and demand projections to 2035 (an energy market assessment) provides a similar projection of oil production growth of 5.8 million b/d by 2035. However, the total energy use in Canada will grow moderately with efficiency changes in using energy (NEB, “Canada's Energy Future”, 2013). Thus, more energy needs to be exported (NEB, “Canada's Energy Future”, 2013). The expected growth of oil exports has become an urgent task for all pipeline companies that have been desperately proposing new pipeline projects or altering old pipelines. These outsideboarder markets include the American market (south), Asian market (west) or Eastern Canada and Eastern America markets (east). The pipeline strategy now is to get tar sand oil out to world markets through the south, west and east. To the south: the Keystone pipeline (Enbridge) has experienced delays by the Obama administration. To the west: the 
Northern Gateway project (Enbridge) gained approval but with 200 conditions and it faces several legal challenges by affected first Nations and other intervenors. The uncertainty of these two major pipeline proposals has pushed pipeline companies to propose reversing the existing eastern pipeline to move tar sands oil out to the east coast of America and even to tidewater ports (to other markets) through the Line 9 reversal project (Enbridge) and the Energy East pipeline project (TransCanada), which converts a gas pipeline to a crude oil pipeline.

\subsection{Intervenors}

\subsubsection{Who are the intervenors?}

According the NEB documents, the Board received applications from 178 interested persons. In the end, there were 60 Intervenors (81 persons) and 111 commenters participating the hearing proceedings of the Line 9 project (NEB, 2014, Reasons for Decision OH-002-2013). 11 persons were only granted the opportunity to participate as commenters instead of as intervenors despite their requests. According to the NEB directives, (NEB, "Applying to Participate in a Hearing", online, n.d.) the person who wants to participate in the hearing must "demonstrate to the Board's satisfaction that they are: a) directly affected by the proposed project; b) they have relevant information or expertise for the Board to consider, or c) both." A commenter can only participate by submitting a letter of comment and doesn't have chance to ask questions about other people's evidence or make a final argument. However, an intervenor who has the chance to "present written evidence, question others on their written evidence, cross-examine other witnesses at the oral portion of the hearing, and give final argument" and does have more input in the 
hearing proceedings (NEB, "What are the typical methods of participation in an NEB hearing", online, n.d.).

Intervenors in the Project hearings fall into 5 categories: Aboriginal Groups, Associations, Companies, Governments and Individuals, according the list of Parties for the Line 9 project from the NEB (NEB, A11-5 Appendix II- List of Parties updated 23 October 2013, A3H8K3). Table 2 shows the number of persons who are on the list.

Table 2: Intervenors

\begin{tabular}{|l|c|c|}
\hline Category & Number of Persons & Percentage \\
\hline Applicants & 6 & $6.9 \%$ \\
\hline Aboriginal Groups & 7 (4 Group) & $8.0 \%$ \\
\hline Associations & 27 (23 Associations) & $31.0 \%$ \\
\hline Companies & 11 (7 Companies) & $12.6 \%$ \\
\hline Governments & 22 (1 Fed, 4 Province, 7 & $25.3 \%$ \\
& Municipalities) & \\
\hline Individuals & 14 & $16.1 \%$ \\
\hline
\end{tabular}

\subsubsection{Win, Not on the Majority Side}

The paper separates all intervenors and applicants into supporter camp members (S-Camp) and opponent camp members (O-Camp) (Table 3 shows the results). A so-called opponent is an intervenor who either had suggested imposing stricter conditions on the project's approval than the NEB decided or had objected to the approval of the project. Based on Table 3, the 0-Camp apparently was in the majority with 62 percent of total 
number of intervenors and applicants. However, the decision did not favour the majority side.

Table 3 Two Camps of the Intervenors

\begin{tabular}{|c|c|l|}
\hline Camp & Number of persons & Percentage \\
\hline Supporters & 33 & $38 \%$ \\
\hline Opponents & 54 & $62 \%$ \\
\hline
\end{tabular}

\subsubsection{The S-Camp: an interest alliance}

It was very easy to figure out that the supporter side included companies and industry associations. Among the supporter camp members, it was easy to tell that it was their interest that united them. Enbridge's main clients filled up the Companies category, including BP Canada Energy Group ULC, Imperial Oil, Marathon Petroleum Trading Canada LLC, Nexen Marketing, Suncor Energy Marketing Inc., Talisman Energy Inc. and an Eastern Canada gas and home fuel retailer, Ultramar Ltd. The supporting associations included: the Alberta Federation of Labor, the Association Indurstrielle De L'est De Montreal, the Canadian Association of Petroleum producers, the Communications, Energy and Paperworkers Union of Canada, the_Conseil Du Patronat Du Quebec, the Quebec Council of Employers, the Federation Des Chambers De Commerce Du Quebec, the Manufacturiers Et Exportateurs Du Quebec, the Ontario Petroleum Institute, and the Progressive Contractors Association of Canada. Compared to the associations on the other side, these industrial associations were more organized and powerful. They were unlikely to worry about expenses of appearing at the hearing proceedings. Their messages were very clear: the Line 9 project was important to Canadian energy security, businesses and jobs and they 
had long-term contracts and job numbers to support their arguments. The only government member in this camp was the Alberta Department of Energy (for the reason, see government intervenors below).

\subsubsection{The O-Camp: safety-centered}

It was far more complicated in the opposed camp. Its members included very determined objectors: the first nations groups and the environmentalist individuals and groups. It also included governments, whose positions varied depending on how strict the conditions they wanted the NEB to impose on the Line 9 project were, because by imposing stricter conditions, they also could seriously delay or jeopardize the approval of the Line 9 project. The main concern among them was almost the same: the safety of the communities and the environments crossed by the 831-kilometer pipeline 9 . The sentiment of the First Nation groups was understandably more complicated than others because of their history.

\subsubsection{The First Nation groups}

There were four Aboriginal Groups involved in the hearing. They were the Aamjiwnaang First Nation, the Chippewas of the Thames First Nation (CTA), the Mississaugas of the New Credit First Nation, and the Mohawk Council of Kahanwa:ke (MCK). The MCK was the most active first nation group in the hearing: there were 4 persons on the list and 3 persons delivered very impressive final oral arguments. After the approval of the Line 9 project, The CTA filed for leave to appeal the decision (See Protests and Appeal). 


\subsubsection{The Government intervenors}

There were 12 government intervenors on the List, which included: the Alberta Department of Energy, the Environment Canada, the Government of Quebec, the Ontario Ministry of Energy, the Toronto and Region Conservation Authority, the City of Toronto, the Municipality of Rigaud, the Municipality of Sainte-Justine-De Newton, the Munnicipality of Tres-Saint-Redempteur, the Municipalite Regionale De Comte De Vaudreuil-Soulages, the Corporation of the City of Mississauga, and the Ville Des SainteAnne-Des-Plaines. Among the governments, local governments tended to express more concerns and wanted to impose stricter conditions on the project than federal and provincial governments because the pipeline was closer to communities and their people. Also, local governments wanted more financial insurance from Enbridge and greater efforts in accident preparedness, including training of responding crews and local fire departments. The provincial governments usually took a more moderate position than municipalities but not without adding more reasonable conditions. For example, Rick Jennings, from the Ontario Ministry of Energy, in the hearing on October 17,2013 stated:

While the province recognizes the vital role pipelines play in our energy system...the project would improve the competitiveness and viability of Quebec's two remaining refineries and therefore provide energy, security and supply reliability benefits to Ontario.... With these significant proposed operational changes, Ontario submits that a cautious approach: third party review of Enbridge pipeline engineering assessment and pipeline risk assessment, given the age... Hydrostatic test: Madam Chair, in our submission, the Board should also impose a condition requiring that a hydrostatic test be conducted on the entire Line 9 prior to the project approval and the results of the test should be taken into account by the Board in 
deciding whether or not to approve the proposed project. (NEB, Hearing Order OH-0022013, Volume6; 4923,4953)

Interestingly, the Alberta Department of Energy representatives had been participating in the hearing without making comments, but always reserved the right to provide final arguments. It seemed that they cared deeply about the project (they had four persons on the list), but the situation appeared satisfactory and Alberta's representatives didn't need to make comments. So we reasonably can assume Alberta was in the S-Camp.

\subsubsection{Environmental and citizen groups, limited resources}

The 14 associations in the 0-Camp could be divided into two Categories: environmental groups and citizen groups including local communities, landowners and farmer groups. The environmental groups included: the Council of Canadians-York University Chapter, the Durham Citizens Lobby for Environmental Awareness and Responsibility Inc., the Equiterre (Coalition), the Great Lakes and St. Lawrence Cities Initiative, the Ontario Pipeline Probe, the Rising Tide Toronto, and the Strategies Energetiques and Sustainable Treant. The citizen groups included: the Algonquin To Adirondacks Collaborative, the Grand River Indigenous Solidarity, the Citizens Au Courant, the National Farmers Union of Ontario and Ecological Farmers of Ontario, the Ontario Pipeline Landowners Association, and the Union of Producers Agriculture. It is worth mentioning that, during the hearing process, the Equiterre Coalition had been playing a leading role in many aspects (see evidence battles). The Equiterre Coalition was made up of seven groups including: the Sierra Club Quebec, the Jeunesse, Nature Quebec, Environmental Defence, the Climate Justice Montreal, the L' Association quebecoise de lute contre la pollution atmospherique, and the lead group Equiterre. 


\subsubsection{Individual intervenors, respected fighters}

There were 14 persons that successfully attained individual intervenor status, but only 12 of them were actually involved in the NEB's hearing and filed comments. All 12 individuals were obviously in the O-Camp, and some of them were environmental activists. They came from different backgrounds: a singer, a political scientist, an environmental health professional, a public health professional, and environment activists (who presented as residents, concern citizens, landowners), but all expressed a great concern about the safety of the community and environment along the Enbridge Pipeline 9. Environmental concerns might have played a more important role for individual intervenors, as they spent their own time and money to participate (the NEB has a participant funding program, but few individuals had applied). Some of them were very actively involved by making oral final arguments and presenting written evidence during the hearing. There was one participant who had even conducted political science research on the public consultation processes for the project, supported by a survey of Burlington residents. Based on her research, she opposed the proposed changes to Line 9. 


\section{Four Interacting and Playing}

\subsection{Introduction}

Having identified the actors in the decision process, the real story will be told by analyzing the interaction among those actors and how the role of those science-based factors, especially probabilistic risk assessment, influenced the outcome. The question addressed in the analysis was whether the decision was based on scientific evidence, on the strength of public participation, or on power of the proponents and their supporters. In a quasi-judicial tribunal format, similar to a civic court, the panel formed by three NEB members heard from competing intervenors with competing evidence to make decisions based on natural justice principles in the Canadian public interest. According the disposition of the NEB's reasons for the decision OH-002-2013 (2014, p. 1), the Board was to "rely on the facts that are established to its satisfaction through the hearing process." This means that the evidence which can eventually become the facts that the NEB's decisions will rely on, is in the hands of the three-member panel. Establishing facts lies at the core of the NEB decision-making process, which had eventually transformed the Line 9 decision-making process into a 'fact war' among all the actors. The interactions among applicants and intervenors had become a 'fact war' between a more solidified S-Camp and a loser O-Camp, which had been striving hard to impose more conditions on or to jeopardize the approval of the NEB. The facts, theoretically, were not hard to find, but in reality establishing the key facts was the most demanding job. The first and most important fact war was the scope battle.

\subsection{The Scope Battle}

Defining the scope of the project was the most crucial step of the Line 9 project approval. Without exaggeration, the winner of this scope battle would win the whole war, 
because the whole war would be based on the agenda and the impact area that had been designated. The scope of the project, which entails three requests from Enbridge, was clearly stated in the NEB document:

On 29 November 2012, Enbridge filed the Application detailing its request 1) to reverse the $639 \mathrm{~km}$ segment of Line 9 from North Westover, Ontario to Montreal, Quebec (Line 9 B), and 2) to increase the annual capacity of the entire Line 9 from 240,00 bpd to approximately 300,000 bpd through the introduction of a drag reducing agent (DRA), while maintaining_a maximum design capacity of 333,333 bpd, pursuant to section 58 (Part III) of the NEB Act. The Application also included a request 3) to revise the Line 9 Rules and Regulations Tariff to allow for the transportation of heavy crude, pursuant to Part IV of the NEB Act." (NEB, Reasons for Decision 0H-002-2013; 4)

In order to achieve the three targets, modifying existing facilities and adding additional pumps and skids and so on were needed. This logic was so apparent that Enbridge's application stated:

The reversal of the flow of Line $9 B$ will be achieved mainly by modifying existing facilities. The increased capacity will be achieved through the addition of pumps and skids that will inject Drag Reducing Agent (DRA) into Line 9 at existing Enbridge facilities. With the exception of some temporary workspace required for the construction of a new densitometer building near Enbridge's North Westover Station, the Project will take place within existing Enbridge properties and right of way (ROW). Project work at Sarnia Terminal, North Westover Station, Hilton Station, Cardinal Station (in Ontario), and Terrebonne Station and Montreal Terminal (in Quebec) includes the modification or replacement of exiting equipment and the installation of pumps and piping within the facility 
boundaries (Enbridge, 2012, Line 9B reversal and Line 9 capacity expansion project application;18).

In this manner, Enbridge successfully narrowed down the scope of the project from the whole Line 9 to only the so-called 'physical scope' of the project: modification, replacement and new installation. It literally reversed the logic of the application, turning the scope of the project for the whole Line 9 into the scope of those few limited changes to the existing facilities and omitting the basic fact that the flow-direction change and capacity expansion and transport of heavy crude would happen along the whole length of Line 9 and potentially affect a wide impact area, not only in the 'physical scope' of new changes. By winning the scope battle, the benefit to Enbridge was huge because if the project was only about those partial modifications, replacements and installations, Enbridge didn't need to increase the insurance coverage to deal with liabilities for the whole Line, and didn't need to conduct a new Environmental Social-Economic Impact Assessment for the existing pipeline parts. This logic was apparent in the ruling of the NEB:

Based on the nature of the application, the Board did not conduct a full review or audit of the current and on-going operations and maintenance $(O \& M)$ work along Line 9, Enbridge's existing integrity management program (IMP), nor its exiting emergency response and environmental management systems (NEB, 2014, Reasons for Decision OH-00202013; 10).

The fallacy of the logic was so obvious, even one of the NEB members, M. Richmond, expressed his suspicions on the first day of the final argument hearing. The conversation between M. Richmond and Mr. Crowther, the council for Enbridge was far more interesting: 
Member Richmond: "Throughout your comments today, in some instances when you talked about the Project, you were referring exclusively to the-well I would imagine the construction site-construction work at six sites. Other times you talked about the benefits of the actions being taken or of the pipeline as a whole of the production going through the pipeline and source, including the change to the tariff to allow heavy crude, which of course doesn't occur at six sites" (NEB, 2013, OH-002-2013 Hearing Transcript, Volume 1, 683). Mr. Crowther: "The Project-you're quite right, I think that information requests indeedperhaps even from the Board-focus in some respects on the physical work involved and define the project in that way" (NEB, 2013, OH-002-2013 Hearing Transcript, Volume1, 689).

The answer Mr. Crowther gave actually revealed another fact: Enbridge could not achieve this reversal of logic without the help of the NEB and the consensus between Enbridge and NEB regarding the scope of the project. But apparently it didn't include Member Richmond as he raised this crucial question and needed to be reminded by Mr. Crowther. This consensus likely happened in the early stages of the application process. If we go back to the timeline of the Project, we will find that on October 11, 2012, the NEB received a pre-application information filing regarding the Line 9 project and one and half months later, November 29, 2012, Enbridge filed the formal application. It is reasonable to assume that the scope of the project was in the conversation or communication between them during that time as this was not a question that could be avoided. From the 0-Camp, several intervenors had pointed out this scope problem, but the strongest one came from Mr. Darko Matovic, from the Ontario Pipeline Probe: 
In conclusion, we submit that the National Energy Board could issue the permit to Enbridge for the works at the particular sites for which it seeks the permit under the current application but should not extend the scope of this permission to include the approval of the flow reversal, flow capacity increase and the change in the product transported to the pipeline since neither Enbridge asked for that in the project nor it provided nearly enough engineering detail and arguments for such modification for use in the pipeline itself (NEB, OH-002-2013 Hearing Transcript, Volume 4, 2990).

By winning the scope battle, Enbridge was already on the right track to win other battles because some things would be beyond the scope of future arguments.

\subsubsection{Out of the scope, a strong excuse}

Out-of-the-scope was reasonably used by Enbridge and the NEB in the proceedings as an excuse for not dealing with many First Nations issues and big scale environmental issues, such as Greenhouse Gasses. We see this in the speech that Mr. Crowther made during the hearing and also the ruling of the NEB below:

Mr. Crowther: "With respect, this hearing is not the proper forum in which to debate these issues. The courts have found that the duty to consult on a proposed project does not include addressing alleged past wrongs" (NEB, 2013, OH-002-2013 Hearing Transcript, Volume 1, 484).

NEB: "Some concerns were raised that are not within the Board's mandate to regulate, such as oilsands development, energy policy, upstream greenhouse gasses (GHGs) and GHGs related to the end use of crude oil" (NEB, 2014, Reasons for Decisions OH-00202013; 2). These of out-of-the-scope arguments are supported by one of the C.D. HOWE Institute's reports: 
I argue that scope creep in regulation is not beneficial for the process (efficiency) or for the decision (effectiveness). It is simply not efficient or effective to attempt to solve broad, farreaching societal challenges, such as First Nations land claims or greenhouse gas emissions policy, through individual project reviews (Doucet, 2012; 13).

Unfortunately, it was contrary to Doucet's 'scope creep' in this case. By deliberately narrowing down the scope of the project, the real consequences of the project would be not adequately addressed in the proceedings.

\subsection{Information Battles}

The second important fact battle was an information battle. How many documents and what degree of information should Enbridge reveal to the public or intervenors? Scrutiny always lies on the front line of this kind of battle. Enbridge usually used two reasons to refuse the information requests from intervenors: the information was not warranted by relevance and it went beyond the level of detail, which could be related to security or privacy issues. John Goudy, OPLA, for instance, was frustrated after the OPLA's information request to Enbridge for an updated environmental assessment that takes account of inspections conducted in the past two years was refused by Enbridge. Enbridge's response is below:

Enbridge objects to the request as it is unduly onerous and unreasonable. The time, effort and expense involved in the compilation of the requested information are not warranted by the relevance, if any, of the information sought, by the significance of the information in the context of the proceeding, or by the probative value of the result (Enbridge, 2013, Exhibit B19-1 Response to OPLA No1-A3I6V0). 
Similarly, Enbridge gave the same response, when the Ontario Pipeline Probe had made a reasonable request for the information below:

Details about all the spills in the last 10 years, that include: 1 The pipeline age; 2 The cause of spill; 3[the] pipe rupture type of material; 4 Type of material failure; 5 Cause of mechanical failure; 6 History of checks for that section; 7 Fluid transported... (NEB, 2013, OH-002-2013 Hearing Transcript, Volume 4; 2983)

These kinds of 'not warranted by the relevance' responses to many information requests from intervenors were directly related to the scope issue. Since the Line 9 project's scope had been confined to limited physical alterations, any information beyond it was out of the scope and deemed irrelevant.

\subsubsection{Summary is enough}

A further information request by OPLA was for a copy of the updated Line 9A Integrity Engineering Assessment (EA) and was objected to by Enbridge and the NEB. In the NEB's ruling Number 4, the Board ruled that:

The requested information goes beyond the level of detail that would be helpful to the Board in this proceeding. The summary information captured in Enbridge's Engineering Assessment is sufficient (NEB, 2013, Exhibit A18-1: Letter to OPLA Ruling No.4, Adobe p 3).

The summary information that the NEB mentioned was basically a statement of conclusions that confirmed the EA was adequate, but it seemed that the NEB judged the statements to be satisfactory. The arguments of security and privacy were used by Enbridge and NEB as justifications to not provide the requested detailed information to intervenors or the public for their scrutiny. 


\subsubsection{Is an information request a fishing expedition?}

By asking for detailed information, OPLA was accused of engaging in a "fishing expedition" by Enbridge. John Goudy responded in the hearing:

No, Enbridge was wrong. OPLA was not engaged in a fishing expedition. OPLA was asking for the analysis to back up Enbridge's claim that everything is fine with Line 9A. OPLA was not satisfied with Enbridge's position that we aren't going to provide you with an updated engineering assessment but trust us, we looked at it and everything is fine (NEB, 2013, OH-002-2013 Hearing Transcript, Volume 6, 5206, 5207).

The examples above represent only a small number of these kinds of information battles during the hearing. Overall, one thing that had became clear was that the 0-Camp was again not successful in this information battle.

\subsection{Evidence Battles}

Evidence Battles, the third kind of core battle, were determined by what kinds of information or research could become true evidence that could carry more weight in the NEB's decisions. The research by Flyvbjerg showed that it was power that determined rationality (Flyvbjerg, 1998). In this case, usually, the written expert evidence tended to carry far more weight than the written evidence prepared by environmental groups or other associations themselves. Expert evidence arguments were more likely to become the facts that the NEB's decisions would rely upon. This was also why, in the final oral argument, Enbridge had focused on attacking the two written experts' evidence provided by the project's opponents: the Goodman Group's Analysis and the Accufacts Report. The two written expert testimonies were both prepared by the Equiterre Coalition, which was the only true challenges to Enbridge in the NEB's proceeding. The two written testimonies had consumed a substantial amount of Enbridge's resources and actually did carry more 
weight in the decision-making of the NEB than the other evidence that other members in O-Camp had put forward.

\subsubsection{The attacks of the Goodman Group's analysis and the Accufacts Report}

Enbridge's reply to the two written expert testimonies was prepared by Demke Management Ltd., a Calgary-based consultant firm focusing on economics, management, and oil \& gas developments. The Goodman Groups is a successful, California-based consulting firm specializing in energy and regulatory economics and regional economic development. Its clients are located throughout the US and Canada. The Goodman Group's analysis had focused on the socioeconomic benefits and costs of the reversal. Economic benefit was the card Enbridge had been playing all through the hearing and in the pubic meetings. But the Goodman Group's analysis directly refuted those benefits found in Enbridge's expert testimonies and the testimonies from oil, refinery and retail companies. Mr. Crowther, from Enbridge, opened fire on the Analysis on the hearing with a sentence: "With respect, The Goodman Group analysis suffers from a number of critical deficiencies..." (NEB, 2013, OH-002-2013 Hearing Transcript, Volume 1; 267,). The Accufacts report was prepared by Accufacts Inc., a 20 year old, Washington-based, publicrecord-research Corporation. The report targeted Enbridge's most controversial element: Line 9's risk of rupture and issues around integrity management. However, Enbridge fought back during the hearing:

We alluded briefly to the Accufacts Report earlier. It is necessary now to address it at some length since it includes, among others, assertions of serious deficiencies affecting Enbridge's pipeline integrity management...It may be that the use of such overblown rhetoric was intended to incite public sentiment against the Project. Regardless, it is completely 
unhelpful to this process and most especially because it has no basis in fact... (NEB, 2013, OH002-2013 Hearing Transcript, Volume 1; 342,345)

The attacks from Enbridge on the Goodman Group's analysis and the Accufacts report had successfully focused on sentimental, unprofessional arguments in order to degrade the credibility of the whole research. For example, Mr. Crowther pointed out: "Indeed, the Accufacts Report goes so far to include a subheading that blares: 'Something appears very wrong with Enbridge's Line 9B risk assessment"' (NEB, 2013, OH-002-2013 Hearing Transcript, Volume 1; 344). The blocking of the detailed information revelations (information battles) had been greatly damaging to the quality of any independent research even before it started. Also, the lack of resources, funding and expert support also limited an equal production of the same level of expert evidence.

\subsubsection{Evidence battles outside the hearing}

Evidence battles also occurred outside the hearing. The headache of facing polarized, confusing information and evidence, was not only experienced by the members of the NEB, but also by those landowners and residents who will be living alongside Line 9. For example, according the report by Baker (2014, March 20), about a hundred landowners attended a video conference with Richard Kuprewicz, an engineer and president of Accufacts Inc., at the Cornwall Civic Complex on March 20, 2014, in order to seek "neutral information" not originating from the two polarized sides: Enbridge and the Environmental groups. Neutral information was something that could more likely become facts to those landowners. However, it was hard to find neutral information in reality. The

people in the S-Camp must have regarded Mr. Kuprewicz as belonging in the O-Camp as his 
company had prepared the most useful report for the Equiterre Coalition (See evidence battles). The evidence battles would eventually push any involved expert to pick a side.

\subsection{Protests and Appeal}

The protests that happened along with the hearing were usually outside the NEB's Court. However, in October, 2013, a group of anti-pipeline protesters stormed into the hearing proceeding at the Metro Toronto Convention Centre and pushed the NEB to postpone the hearing. The NEB expressed its frustration in its document:

The Board expects Participants and other members of the public attending its hearings to act with courtesy and respect during the proceeding. Unfortunately, this was not always the case. The Board takes seriously the unfortunate instances during which Parties were interrupted by individuals attending the hearing at both venues. Ultimately, this lack of decorum and disruptive conduct resulted in the final day of oral argument being cancelled, due to concerns with respect to the security of attendees (NEB, 2014, Reasons for Decision OH-00202013, p.13).

After that, the NEB made its final decision, according to news in The First Perspective, "The Chippewas of the Thames First Nation filed for a leave to appeal federal regulator's green light to reverse and increase flow on Enbridge's aging Line 9" (McDiarmid, 2014, online n.d.).

\subsection{Is the Public Participation a "Mere Lip Service"?}

Public participation has been widely implemented in many regulatory decisionmaking practices for many years, and it is listed first on the NEB's reasons for its decision on the Project. The chapter opened with: "Effective public participation facilitates understanding between stakeholders, improves decisions and acknowledges the desire of 
interested persons to participate in decisions which affect them" (NEB, 2014, Reasons for

Decision OH-00202013, p13). Despite this, throughout the hearing, many participants had expressed frustrations about the public participation and engagement process including rushed notices, not being informed or being ill-informed, and meetings being hosted after passing the participation deadline. It might have become a public disengagement program in terms of its effectiveness. An individual intervenor had even conducted a survey of Burlington residents and political scientists to prove it. A lawyer from the First Nation Mohawk Council of Kahnawa:ke (MCK) called those public engagement programs "mere lip service" (NEB, 2014, OH-002-2013 Hearing Transcript, Volume 2;1326). However, The Board expressed a different 'third-party' view about the participation program: improvement was needed but it was adequate.

\subsection{Did Science-based Factors Play A Role?}

In the NEB's Line 9 Project decision-making process, there were very important key science-based measurements, which could indicate if the pipeline's engineering, safety and environmental standards would be actually met. Based on the analysis, not surprisingly, this research found that even some of the most basic science-based and technical measures had different versions depending on which camps they came from. Enbridge had been apparently reducing the risk by narrowing down the scope and increasing the economic benefits of the project. The environmental groups had faced serious information blockages, which greatly increased suspicions about everything Enbridge had said. They had been trying very hard to probe, to falsify, and even to guess what was really happening to the Enbridge's pipeline underground. It even reached the point where the more crucial the science-based factors were, the more disputed they were because those factors were 
the key measurements for the approval of the Line 9 project. In the end, the role those science-based factors played fell on the judgments and expertise of the NEB. In terms of science-based factors, this paper will only focus on the most important components, like the Environmental Assessment, the Pipeline Risk Assessment, the Pipeline Integrity Engineering Assessment and some of most disputed technical issues in the hearing, such as Hydrostatic Testing. As those science-based factors are beyond the expertise of the researcher, what the paper investigates is only how those technical factors had been presented by those actors. However, problems embedded in those factors were shockingly obvious and serious.

\subsubsection{No Environmental and Socio-economic Assessment (ESA) needed}

The NEB's ruling that no further assessment for ESA was necessary was not surprising because Enbridge had won the scope battle. In this narrow scope logic, it would be: "Where there were no potential Project-environment interactions, or where the potential interaction would be positive or neutral" (NEB, 2014, Reasons for Decision OH00202013; 74). Then many participants' concerns about the environment and community safety were easily and reasonably blocked by the fact that this was an existing pipeline, not a new project. If this is the case, what about Enbridge's planned 600 and more excavations for Line 9 (more digs are expected in the future); Would there still be no projectenvironment interaction (See Future tense)?

\subsubsection{The Risk Assessment changes}

The Pipeline Integrity Engineering Assessment, along with the Pipeline Risk Assessment, were the most important crucial science-based tools among the science-based measurements, because they could address directly the largest safety issues about this 38 
year old, 30-inch pipeline. Enbridge's the Pipeline Risk Assessment of Line 9B Reversal and Line 9 Capacity Expansion Project appeared in the form of the Appendix B to the Pipeline 9B Engineering Assessment. The Pipeline Integrity Engineering Assessment 9B was prepared by the Pipeline Integrity Department of Enbridge, dated November 2012, which was just before the application of the Project. The conclusion of the pipeline Risk Assessment is found below:

In summary, the Line $9 B$ reversal portion of the project will result in minor increases of risk to the operation of the pipeline at the discharge side of the pump stations (North Westover, Hilton, Cardinal and Terrebonne). The reversal of Line 9B will result in minor decreases of risk to the operation of the pipeline at the suction side of the pump stations (Hilton, Cardinal, Terrebonne and Montreal). An increase in risk will be realized for approximately $0.9 \%$ of Line 9 as a result of the proposed capacity expansion portion of the Project (Enbridge, 2013, The Pipeline Risk Assessment Line, P9).

However, during the hearing, a revised Pipeline Risk Assessment from Enbridge aligned with its recent new In-Line-Inspections (ILIs) testing data in 9B was presented, and suddenly the risk section percentage increased from $0.9 \%$ to $2.2 \%$, almost 2.5 times higher than before. More importantly, there was not an event probability provided in those risk sections. But it was still fairly safe according to Enbrdge:

Enbridge: "The project would increase Line 9's capacity. And that increase would result in an increase in assessed risk for 2.2 percent of the pipeline. To be clear, that does not mean a 2.2 percent of the pipeline higher risk overall. In fact, only 60 of the 2,730 total 305- meter long pipeline sections between Montreal Terminal and North Westover Station display an increase in risk"(NEB, 2013, OH-002-2013 Hearing Transcript, Volume 1; 329). 
As we see, the number in the Risk Assessment can be changed easily and the Board still approved the project. The judgment of Risk acceptability was in the control of the NEB. A public acceptance of the risk was not established. But the larger surprise came from the pipeline Integrity Assessment.

\subsubsection{Future tense, the updated Pipeline Engineering Assessment}

In the completed Pipeline Integrity Engineering Assessment (Enbridge, 2012), there were planned activities prior to flow reversal, which were listed on Item 5 , just before the conclusion:

[To] conduct a comprehensive ILI program targeting metal loss, cracking and geotechnical features between $M L$ and NW; evaluate the results of the ILI program and reassess pipeline integrity based on 2012-2013 inspection data; determine what line rehabilitation activities are required to maintain the integrity of the pipeline; and execute required excavations and rehabilitate the pipeline to maintain pipeline integrity and meet the required operating parameters as per the Enbridge Integrity Management Plan (Enbridge, 2013, the Pipeline Integrity Engineering Assessment, p.94).

However, this unfinished work didn't prevent the report from coming to the conclusion at the next Item 6: "The overall results of this EA thereby demonstrate that the Project can proceed in a safe and reliable operating condition" (Enbridge, 2013, the Pipeline Integrity Engineering Assessment, p95). It is not clear how Enbridge, supported merely by unfinished data, jumped to this conclusion, and how Enbridge could easily change a number in the risk assessment so dramatically. How could affected populations believe the conclusion in the Enbridge assessment was reliable? More surprisingly, the 
completion date of this on-going pipeline test described during the hearing was in the future, and it would continue after the NEB's approval of the project.

Moreover, according to the NEB, Enbridge had planned over 600 excavations for Line 9, which related to verification digging and repairing. Participants might expect that these excavation numbers related to 'rehabilitation activities' would rise after the approval, because Enbridge was still testing its pipeline. But future works would not be under public scrutiny. Those significant 'rehabilitation activities' definitely exceeded normal maintenance repairs, going far beyond the application scope that Enbridge and the NEB had defined. But the biggest drama belongs to the NEB's approval of the Project in light of those strategic maneuvers by Enbridge.

\subsubsection{No third party review necessary}

Enbridge's maneuver of suddenly increasing the risk value had aroused the suspicions of the Ontario Ministry of Energy (OME), which decided to support the Ontario Pipeline Landowners Association (OPLA) to request an independent third-party review of Enbridge's Updated Engineering Assessment (Updated EA), including the Risk Assessment. These suspicions were raised about both Enbridge and the NEB, because the OME should have known that the NEB had experts to conduct the review. Not surprisingly, the NEB's ruling is below:

The Board is an independent, expert agency with technical expertise to provide oversight over a wide variety of pipeline design and operation...The NEB staff are fully qualified to support the Board in carrying out its mandate, and the Board has the technical expertise to conduct a review of Enbridge's Updated EA, as required by Condition 9 (NEB, 2014, Reasons for Decision OH-00202013; 50). 
The message from the NEB was very clear: Don't worry, everything is under the NEB's control and trust us. The question was whether the board's specialists should have been reviewing Enbridge's first assessment and the revised version of the assessment before the approval of the project since safety is the top priority of the NEB. However, the oversight actions of NEB experts were not explained.

\subsubsection{Hydrostatic Testing or In-Line Inspection?}

The key dispute focused on which technical method should be used to examine the pipeline's current condition, Hydrostatic Testing or In-Line Inspection; it had been creating a lot of heat for the participants, and even among the public. Enbridge's choice was In-Line Inspections and the reason was explained below:

Hydrostatic testing is not a panacea. In fact, it is not the primary method utilized by pipeline operators that are able to use high-resolution In-Line Inspection tools for integrity verification. One reason is that hydrostatic testing only provides confirmation at a particular time that the remaining defects in the pipeline have dimensions smaller than a critical defect size. The reality is that a successful hydrostatic test does not guarantee that the pipeline in question will not fail in the future (NEB, 2013, OH-002-2013 Hearing Transcript, Volume 1; $355,356)$.

However, the first recommendation from the Accufacts Report (Equiterre commissioned) was the recommendation that Enbridge conduct a hydrotest before the reversal operation. In the report, it further stated:

Based on the preponderance of information from the NTSB investigation, Accufacts finds that Enbridge has a culture of denial when it comes to the strengths of hydrotesting and a highly distorted over-reliance on ILI inspection on crack detection that has yet to be 
sufficiently proven to assure pipeline integrity for certain extensive SCC and/or corrosion fatigue cracking threats on Line 9. Accufacts finds Enbridge's statements concerning the possible damage from hydrotesting are without technical merit, and appear to be attempts to misinform decision makers and the public (Accufacts Inc, 2013, Report on Pipeline Safety for Enbridge's Line 9B Application to NEB; 30).

The NEB's decision was that Enbridge could continue to proceed with ILI but to leave the door open for requiring hydrotesting later on before granting Enbridge the Leave To Open (LTO), in consideration of the Updated EA, new repairing conditions and ILI tool reliability. This has become a normal business practice between the NEB and Enbridge. However, the challenges would not have been possible without the Accufacts and the Equiterre. 


\section{Five Key Factors}

\subsection{Introduction}

Up to this point, the paper has tried to tell the story of the Line 9 Project's approval process by presenting the timeline and analyzing the actors and the interactions among actors based on the evidence that has been recorded in the hearing transcripts, the filings, the written evidence, the regulations, the reports, and other sources of information, such as newspapers, and websites. Going forward, based on prior analysis, the paper will provide an analysis of the factors that had influenced the NEB ruling in order to further understand the true nature of this decision-making process. The paper will focus on the key factors that have been demonstrated in the previous analysis.

The conflict-centered approach naturally led the investigation to the power analysis that Foucauldians have applied for many years. Such researchers, as they relate to theoretical findings in the planning literature, include: Flyvbjerg (1998), Yiftachel, et al. (2001) and Taylor, Kim \& Gahbauer, (2009). In the prior analysis, the paper found that the two camps both had been wielding their power to present rationalization as rationality, even though the power between them was asymmetrical. This finding reinforces Flyvbjerg's finding that "Rationalization presented as rationality is shown to be a principal

strategy in the exercise of power" (Flyvbjerb, 1998; 2). Further, the NEB's decision-making process mainly turned into a competition of rationalizations. The rationalizations of the two camps were evident in the scope battle, information battles, and evidence battles. Given the conflicting roles embedded in the establishment of the NEB, the Board also needed a rationalization to dress up its decision as a more rational one. In this 'fact' establishing process, true facts and false facts (products of the rationalization) would have 
both been established. However, to what extent the rationalization can be realized in this quasi-independent, quasi-judicial tribunal authority is the most crucial question.

\subsection{Key factor 1: Three-Member Panel}

Among the current setting of the NEB, in this paper's power analysis perspective, the Three-Member Panel is the key factor influencing the decision. How these three members exercised their power, depended largely on their backgrounds and expertise. In order to probe this panel, a background check is necessary. Three members in the panel of this Project include L. Mercier (Chairperson), M. Richmond and J. Gauthier. In order to invite reader to become involved in the analysis, the paper lists their original profiles posted on the NEB's website below:

Lyne Mercier:

Ms. Mercier was designated as Vice-Chair and Alternate CEO of the National Energy Board of Canada (Board) On June 12, 2014. [After the ruling of the Line 9 Project]) Her term is for a period of seven years, on a full-time basis. Ms. Mercier was first appointed as a permanent, full-time member of the NEB on December 17,2008, for a term of seven years. Before joining the NEB, Ms. Mercier worked at Gaz Metro for over 29 years, serving 10 year in executive positions. At Gaz Metro she was director of the gas supply division, where she was responsible for strategic policy for natural gas supply and for the management of natural gas transmission, storage and supply contracts. Prior to that, She was head of the pricing division, where she was responsible for toll design and cost-of-service allocation studies. Ms. Mercier holds a Bachelor of Commerce from St. Mary's University and an Executive MBA from I'Ecole des Hautes Etudes Commerciales (NEB, “Board Members”, online, n.d.). Mike Richmond: 
Mr. Richmond was appointed as a temporary member of the NEB on November, 1, 2012. His term is for a period of three years, on a part-time basis. Mr. Richmond holds a law degree from the university of Toronto and a Bachelor of Social Science degree from the University of Ottawa. Originally from Montreal, Quebec, Mr. Richmond practices law in Toronto, Ontario at MCMillan LLP, where he is co-Chair of the Energy and Power Group. As an energy lawyer, Mr. Richmond has extensive experience in electricity, renewables and utilities. From 2001 to 2001, Mr. Richmond served the Government of Ontario as a Senior Energy Policy Advisor during the restructuring of Ontario's electricity markets. In addition, Mr. Richmond has served on the Board of Directors of Toronto Hydro Corporation, Canada's largest municipal electric utility, and on the Board of the Ontario Energy Association. In recent years, he has served as a guest lecturer on energy policy at Queen's University (NEB, "Board Members", online, n.d.). Jacques Gauthier:

Jacques Gauthier holds a Bachelor of Law degree from the University de Sherbrooke and is a member of the Bar of the province of Quebec. Mr. Gauthier was appointed on a three year term as a temporary member of the National Energy Board effective 13 December 2012. Mr. Gauthier's most recent position before joining the Board was serving as the President and Chief Executive Officer of LVM Inc. and Senior Vice President of Dessau Inc. Throughout his career, Mr. Gauthier has contributed to the creation and development of major energy projects in both Canada and the United States. In addition, he has held the position of President and CEO of one of Canada's largest private electricity producers and North American Leader in wood residue power generation. He has served on a wide variety of boards and committees, including the Canadian Olympic Committee, the Quebec Wildlife 
Foundation, and the Prime Minister's Advisory Committee on the Public Service. In 2012, Mr. Gauthier was the personal envoy to the prime minister of Canada for official languages and president of the Advisory Committee on Official Languages for the Vancouver 2010 Olympic Games. Mr. Gauthier is passionate about Official Languages, a guest speaker at numerous Quebec business and energy industry forums, and sits as a judge on the federal penitentiaries disciplinary court. In 2012 Mr. Gauthier received the Mercuriades Award in recognition of excellence in Occupational Health and Safety (NEB, "Board Members", online, n.d.).

From the above, we learned that two of the three members excluding Mr. Richmond, came directly from the energy industry and had been in very high positions (especially Mr. Gauthier) in the companies they served. As the paper mentioned before, Enbridge indirectly, partially owned Gaz Metro that Ms. Mercier worked for. These two people were clearly insiders in the Energy sector and Mr. Gauthier even enjoyed wide social ties with the Canadian energy sector, government and even political leaders.

Based on the hearing transcript, the first question that Mr. Gauthier asked was about language, some issues with Enbridge's French version filing. This reflected his passion for Official language issues in the profile. Mr. Richmond was the only Member who had challenged Enbridge and its allies by asking key questions, for example the scope question. Two Members held law degrees and one with a commerce and MBA degree. None of the panel members had any competence in risk assessment, environmental assessment or physical environmental science. In terms of the decision, the discussions and voting among the three members were held behind closed doors. But based on the final decision, it was not hard to tell that Enbridge had very strong support on the Panel. 


\subsection{Key Factor 2: Information Transparency}

Another key factor is information transparency. Information inside Enbridge and the NEB can become public information through free and timely information flow. In this case, opponent intervenors desperately wanted to increase the information flow by filing many information requests to Enbridge. But Enbridge decreased the information flow by refusing many requests and even blaming some intervenors for engaging in 'fishing expeditions.' Whoever controled the information flow had more power to exercise rationalization. (Forester, 1989) The Information control itself was one type of power relation, as interest groups tended to keep secret the information that opponents could utilize and revealed the information that could be used to advance their interest.

The NEB could also control the information flow by limiting the scope and details of publicly accessible information or by objecting to information requests from Interveners. There are also a number of aspects of how the NEB works that remain opaque, especially aspects related to how they audit the construction and operation of pipelines. The public participation and engagement program in this case did not offer much help in maintaining information transparency.

\subsection{Key Factor 3: Expert Resources}

Expert resources also were a decisive factor in influencing the decision-making process. The apparent imbalance of expert resources between two camps had been demonstrated during the hearing in many ways. Among the many environmental and citizen groups, the lack of expert resources was the biggest challenge in protecting their interests. Most intervenor groups relied on a few members who happened to be engineers to volunteer their expertise, and often they lacked financial resources to commission the more respected experts or consultant firms to provide written expert evidence. However, 
there was only one organization, Equiterre Coalition, that could commission an American company to write a report specific to this hearing. The attack from Enbridge on these two written expert testimonies (see evidence battles), the Goodman Group's analysis and the Accufacts report, demonstrated the power of the two expert documents. Their power could also be observed in the NEB's 'Reasons for Decision' document, as it cited the evidence in the Accufacts Report many times to support its decision. From the paper's view, the Equiterre Coalition was the most advanced player among the 0-Camp members. It was the only group that had exercised the most powerful weapon, expert evidence, to challenge Enbridge.

Unlike opponent groups, Enbridge had many full-time experts inside the company and never hesitated to hire outside consultants firms when needed. The number in the pipeline risk assessment could be changed very easily by its staff. The industry itself has been cultivating many experts and successful work experience in the industry was the most preferred criterion for choosing a member of the NEB. This gave Enbridge a natural advantage. Moreover, Enbridge and its allies are the big consumers for both energy industry-related new technology or consultant firm services. The experts in those firms would reasonably be reluctant to work for environmental groups for fear of irritating their biggest clients. The specialists in the NEB also came from the industry or related engineering technology companies. Once they find positions in Government, they will gradually lose the edge of their expertise. All of these factors would give the advantage to Enbridge to win any expert war. However, the example of the Equiterre Coalition has raised the hope of joining together to form a coalition in order to gather more expert resources or more financial sources to commission expert reports, even research. 
Coalition formation is the strategy advanced by Tore Sager to become power relations in the planning process (2013).

\subsection{Key factor 4: Tighter Coalitions Create Power}

In any society, common sense tells us that more alliances result in more power.

From the study, it was very clear that Enbridge and it supporters had formed very cohesive coalitions. They came up with well-prepared evidence that supported each other's interests closely. This indicated that the communications among them were effective. As a example, the Alberta department of Energy felt no need to make comments during the hearing process. However, it was another story in the 0-Camp. The governments, social groups and individuals didn't form any type of united coalition, even though they all opposed the approval with such limited conditions. Their interests were loosely associated with the same concerns: the safety of the community or the environment. Most of the governments did not object to the approval of the project, but would have liked to impose more strict conditions to ensure safety. The only coalition was the Equiterre Coalition, which only included six groups. It is very difficult to form a coalition among different types of associations inside the 0 -camp because an alliance needs strong leadership and commitment to unite such diverse interest groups. Even so, a coalition may be the only hope for environmental groups and landowner groups to gather more power in future battles. Sager responded to the no-strategy-against-power argument by suggesting an actual role for planners the builds "an alliance with activist organizations external to the planning process and encourage them to put pressure on stakeholders that act self-serving at the expense of broader interests" (Sager, 2013, p. xix) 


\section{Six Conclusions}

This paper has reviewed the record of the NEB hearings and told the story of the Line 9 project approval through a timeline, historical context, analyzing main actors, analyzing interactions among main actors, analyzing how science-based factors played a role, and finally analyzing some key factors that influenced the decision. The answer to the research question has become crystal clear and very simple: the decision that the NEB made on the Line 9 Project was not a science-based decision. The reduced scope of the project did not adequately address the real scope, which greatly underestimated the risk of flow reversal and capacity expansion for the aging pipeline. Many reasonable concerns of the intervenors had been blocked by the rationalization that information requests were out of scope. The real project would not receive closer public scrutiny given the power relations that have guided the business between the NEB and Enbridge. There was no evidence in the proceedings to demonstrate the NEB's own claims to expertise. Nor were the members of the panel at arms length from the energy sector, and further, lacked the required expertise. The decision-making process and the final decision were not sound and it did not boost the public confidence, but, in fact, lowered it. 


\section{Seven Indications and suggestions}

The conclusions of this research reinforced the observations that many researchers (Flyvbjerg (1998), Yiftachel, et al. (2001), Taylor, Kim \& Gahbauer, (2009), and Forester, 1989) have made: the misuse of power is an effective means to serve powerful interest groups, to rationalize decisions, and to manipulate and distort information; and the lack of power for experts and specialists, including planners, is evident in decision-making processes. It will be not necessary for this paper to further reiterate these similar findings, but rather to focus on seeking further indications, and even suggestions based on these findings. Like the Flyvbjerg's case study, the Line 9 project "may be interpreted as a metaphor of modern politics, modern administration and planning and modernity itself"(Flyvbjerg, 1998; 225).

\subsection{Indication 1: It is interests that motivate the rationalization}

In the NEB's hearing process, the applicants and its supporters went through the current formative process by presenting application evidence (fact, reasoning, sciencebased factors) to get approval. The opposed intervenors intervened in the process by presenting counter-evidence (facts, reasoning, science-based factors) to either stop the project or impose conditions. The S-Camp members and the 0-Camp members are both interest groups by nature. For an interest group, it is its nature to achieve its goal, not rationality, and not in the public interest. In this particular case, the S-Camp's goal was to get approval without having more conditions imposed upon it to suit its interests: more profit at lower cost. The 0-Camp's goal was to oppose the approval or impose more stringent conditions, mostly motivated by the safety concerns about communities and the environment. The S-Camp members wanted to lower the cost of safety, and at same time 
the 0-Camp members wanted to impose more conditions (at whatever cost) to ensure safety. In order to achieve their goal or to suit their interests, both camp members would naturally present rationalization as rationality, a principal strategy to sway the decision of the third party in favoring their interest (Flyvbjerg, 1998). This means it was interest that motivated rationalizations, and power was only a tool to realize those rationalizations. This indicates where interests are, where rationalizations will be and the more powerful the interest groups are, the more rationalizations can be achieved. If this is the case, the core objective of decision-making in the NEB or planning process will be how to keep distance from interests by establishing an independent third party.

\subsection{Indication 2: A better decision-making format and a true third party authority solution}

Even though our findings were not encouraging, the intended format of the NEB decision-making process is actually better than many decision-making processes in planning, because there was an effort of establishing a third-party role with authority to deal with interests. The legitimacy of the NEB authority and its power comes from the legislation of the Canadian Parliament. The NEB's regulatory power is evident in its ruling. The basic idea of this triangle-like process is that the third part (with authority) made judgments to regulate international and interprovincial aspects of the oil, gas and electric utility industries in a quasi-judicial process. The Third Party's ruling was supposed to be based on natural justice principles, evidence (fact, science-based factors), implementation of the regulations and policies (affirmed by legislation) and rationality. However, this research revealed that the NEB was not a real third party. It was a quasi-one, which was subject to the influence of political-economic powers. Thus, the essential problem of this NEB decision was not in the format of this decision-making process, rather it was on how 
to best establish an independent third party authority. By comparison, in a planning process, planners seem to play a third-party role but without the legitimate authority to make final decisions, which makes planners vulnerable to fulfill their jobs "in the face of power" (Forester, 1989; 1). Without true third party authority, it is hard for any decisionmaking process in reality to be fair, open, and able to integrate all the facts, reasoning and science-based factors rationally, because "Power concerns itself with defining reality rather than with discovering what reality "really" is. This is the single most important characteristic of the rationality of power, that is, of the strategies and tactics employed by power in relation to rationality... power defines what counts as rationality and knowledge and thereby what counts as reality" (Flyvbjerg, 1998; 227). The indication here is that the solution for improving decision-making quality lies in the capacity for a society to establish a true third part agency, which can keep a real arms-length distance from the influences of political and economic interests and does not have any inherent functional conflicts.

\subsection{Indication 3: Science-based factors and empowering expert communities}

The safety issue raised the most crucial technical concerns in this case. To estimate whether the Line 9 project would be safe, science-based methods were critical. One of the key measurements was the Pipeline Integrity Engineering Assessment, which included the Pipeline Risk Assessment. In order to testify regarding these science-based methods, the Third-party certification was not only necessary, but also essential (as many intervenors recommended in this case). In the current setting, the NEB claimed it was also qualified as a Third-party Certifying Authority. Regardless, granting that the NEB has the capacity and authority to conduct such a review, the specialists that have conducted the review must come to the tribunal to testify in front of all the participants before the approval. The NEB 
was supposed to act in the Canadian public interest through communication, discourse, debate, and third-party review when necessary. To do so, it required that rationality and justice be the goals pursued in the public interest. When it referred to economic, technical and financial feasibility of the project, it implied rationality, and when it referred to environmental and socio-economic impacts of the project, the process was supposed to seek justice in the public interest. However, rationality and justice both require knowledge and expertize, which indicates that we should empower expert or scientific communities not political agents. When specialists come to the front in the NEB tribunal, the sciencebased factors become more important matters in the decision-making proceedings, and the empowerment of experts becomes possible. On the contrary, when a regulatory body (a third party) cannot adequately exercise and demonstrate its fairness and openness, and most importantly its capacity to re-examine science-based methods, the decision-process not only cannot solve the problem, but also will worsen the situation, in which all participants will not benefit. It was an extraordinarily formative defect in the current proceedings of the NEB to not have adequate experts on the panel (See key factor 1) and not to let their specialists testify publicly, in stead to keep the process in a 'black box', which aroused the distrust of the public, and further intensified the tension between development of the energy sector and environment safety concerns of the public.

\subsection{Indication 4: The cure for the dilemma in the public interest lies also in the truthfulness of a third party authority \\ Given the pipeline's nature, the concerns from the 0-Camp members easily became a public interest issue because a serious pipeline accident would have great impact on a large number of people, places and the environment (especially water bodies). However, the Applicant, backed by an alliance, also represented the public interest to some extent:}


the energy sector and its economic importance. Thus, the third party faced an extreme dilemma, as it also happened to be the representative of the public interest. Even Doucet (2012, p12), from the C.D. HOWE institute, pointed out the fundamental problem of current government regulation processes: "However, they shy away from a prescriptive or a priori weighting of factors, and do not precisely define the public benefit or public good of a project". However, the hope for a cure to this public interest dilemma is not in Governments' hands, but in the truthfulness of a third party view and its authority. This is simply because the establishment of a Government process was always based on the political struggles among interested parties. The fairness of a decision-making process lies in the truthfulness of a third party authority.

\subsection{Suggestions for the NEB}

Considering the significant accumulation of public awareness of environmental issues recently in Canada and the Line 9's uniqueness in crossing the most populated area in Canada, the NEB missed an opportunity on the Line 9 project to adequately address the issues. Based on the research, the NEB should make a series of changes, which include: the formative defect in the NEB proceeding should be fixed, information transparency should be improved, the pubic participant and engagement program should be improved, the science-based factors should be taken more seriously and be put at the center of decisionmaking, the specialists inside the NEB should come to the front to demonstrate the Board's expertise capacity. From this paper's perspective, these changes will be crucial to assure the real safety of the pipeline, and to ease the mounting political tension between the energy sector that wants to quickly expand its business to overseas markets and the public that is motived by great concerns about environmental issues. 


\section{Appendix 1: $\quad$ Main Actors in the Line 9 Project Proceeding}

\begin{tabular}{|c|c|c|c|c|}
\hline Intervenors & NEB & Three-Member Panel & Intervenors & \\
\hline & & Intervention & & Firct Nation \\
\hline Support Camp & & Intervention & Oppose Camp & rilst ivatuon \\
\hline
\end{tabular}

\begin{tabular}{l} 
Applicant: Enbridg \\
\hline \multicolumn{1}{|c|}{ Company } \\
\hline BP Canada Energy Group ULC \\
\hline Imperial Oil \\
\hline Marathon Petroleum Trading \\
\hline Nexen Marketing \\
\hline Talisman Energy Inc. \\
\hline Ultramar Ltd. \\
\hline
\end{tabular}

\section{Association}

Alberta Federation of Labor

Association Indurstrielle De L' est De Montreal

Canadian Association of Petroleum producers

Communications, Energy and Paperworkers Union of Canada

\section{Conseil Du Patronat Du Quebec}

Quebec Council of Employer

Federation Des Chambers De Commerce Du Quebec

Manufacturiers Et Exportateurs Du Quebec

Ontario Petroleum Institute

Progressive Contractors Association of Canada

Government

Alberta Department of Energy
Aamjiwnaang Frist Nation

Chippewas of The Thames First Nation (CTA)

Mississaugas of the New Credit First Nation

Mohawk Council of Kahanwa:ke (MCK)

Government

\section{Environment Canada}

Government of Quebec

Ontario Ministry of Energy

Toronto and Region Conservation Authority

City of Toronto

Municipality of Rigaud

Municipality of Sainte-Justine-De Newton

Munnicipality of Tres-Saint-Redempteur

Municipalite Regionale De Comte De Vaudreuil-

Soulages

The Corporation of the City of Mississauga

Ville Des Sainte-Anne-Des-Plaines.

\section{Environment Group}

Council of Canadians-York University Chapter

Durham Citizens Lobby for environmental Awareness and Responsibility Inc.

Equiterre (Coalition)

Great Lakes and St. Lawrence Cities Initiative

Ontario Pipeline Probe

Rising Tide Toronto

Strategies Energetiques

Sustainable Treant

\section{Citizen Group}

Algonquin To Adirondacks Collaborative Grand River Indigenous Solidarity

Citizens Au Courant

National Farmers Union of Ontario and Ecological

Farmers of Ontario

Ontario Pipeline Landowners Association,

Union of Producers Agriculture 


\section{References}

Accufacts Inc. (2013). Report on Pipeline Safety for Enbridge's Line 9B Application to NEB.

Retrieved from https://docs.neb-one.gc.ca/ll-eng/llisapi.dll/fetch/2000/90464/ 90552/92263/790736/890819/956564/956632/981386/C13\%2D6\%2D3_\%2D_ Attachment_B\%2D_ACCUFACTS_PIPELINE_SAFETY_REPORT\%2E2013\%2E08.05_ \%2D_A3J7T4.pdf?nodeid=981150\&vernum=-2

Baker, Lois. (2014, Mar 20) Landowners hear from pipeline expert. Cornwall StandardFreeholder. Retrieve from http://www.standard-freeholder.com/2014/03/20/ landowners-hear-from-pipeline-expert

Blanchfield, M. (2006, Jul 15). Harper calls Canada 'energy superpower,' chides Russia. Star

- Phoenix Retrieved from http://ezproxy.lib.ryerson.ca/login?url=http:

- //search.proquest.com/docview/348759387?accountid=13631

Burn-Pieper, A. (2014, Feb 21). Line 9 has had significantly more spills than previously stated, W5 reports. CTV news. Retrieved from http://www.ctvnews.ca/w5/line-9-has-had-significantly-more-spills-thanpreviously-stated-w5-reports-1.1698286

CAPP. (2014). Crude oil forecast, markets \& transportation. (2014). Canadian Association of Petroleum Producers. Retrieved from http://www.capp.ca/getdoc.aspx?DocId=247759\&DT=NTV

Caron, G. (2014). Reflections on 35 years with the National Energy Board, 2014. Retrieved from http://www.neb-one.gc.ca/clf-nsi/rpblctn/spchsndprsnttn/ 2014/rflctnsn35/rflctnsn35-eng.html

Corcoran, T. (2010, Apr 30). The reverse national energy program. National Post. 
Retrieved from http://ezproxy.lib.ryerson.ca/login?url=http://search.proquest.com/ docview $/ 230805199$ ?accountid=13631

Doucet, J. (2012). Unclogging the pipes: Pipeline reviews and energy policy. Commentary C.D.Howe Institute, (342), 0_1,1-21. Retrieved from http://ezproxy.lib.ryerson.ca/login?url=http://search.proquest.com/docview/928065411 accountid=13631

Doern, Bruce (edit) (2005) Canadian energy policy and the struggle for sustainable development. University of Toronto Press, 2005, ISBN 9780802085610

Enbridge. (n. d. ) Our Pipelines. Enbridge Website. Retrieved from http://www.enbridge.com/DeliveringEnergy/OurPipelines.aspx

Enbridge, 2012, Line 9B reversal and Line 9 capacity expansion project application. Retrieved from https://docs.neb-one.gc.ca/ll-eng/llisapi.dll/fetch/2000 /90464/90552/92263/790736/890819/918445/890501/B1\%2D2_\%2D_ Line_9B_Reversal_and_Line_9_Capacity_Expansion_Project_Application_\%2D_ A3D7I1.pdf?nodeid=890345\&vernum=-2

Enbridge. (2013).The Pipeline Risk Assessment Line 9B Reversal and Line 9 Capacity Expansion Project. Retrieved from https://docs.neb-one.gc.ca/ll-eng/llisapi.dll/ fetch/2000/90464/90552/92263/790736/890819/918445/890501/ B1\%2D17_\%2D_Appendix_B_to_Pipeline_Engineering_Assessment_\%2D_ A3D7J6.pdf?nodeid=890254\&vernum $=-2$

Enbridge. (2013). The Pipeline Integrity Engineering Assessment Line 9B Reversal and Line9 Capacity Expansion Project. Retrieved from https://docs.neb-one.gc.ca/lleng/llisapi.dll/fetch/2000/90464/90552/92263/790736/890819/918445/ 
890501/B1\%2D15_\%2D_Attachment_7_\%2D_Pipeline_Engineering_Assessment_ \%2D_A3D7J4.pdf?nodeid=890442\&vernum =-2

Enbridge. (2013, June 25). Exhibit B19-1 Response to OPLA No1-A3I6V0. Retrieved from https://docs.neb-one.gc.ca/lleng/lisapi.dll?func=ll\&objId=964209\&objAction=browse\&viewType=1

Flyvbjerg, Bent (1998). Rationality \& power-democracy in practice. The university of Chicago press.

Forester, John. (1989). Planning in the Face of Power. University of California Press.

Financial Times. (n.d.) Business profile: Enbridge Inc. Retrieved in 2014 from http://markets.ft.com/ft/tearsheets/businessProfile.asp?s=ENB\%3ANYQ

Gaz Metro. n.d. Corporate Structure. Retrieved from http://www.corporatif.gazmetro.com/lentreprise/structurecorporative.aspx?culture=en-ca

Getman, C. (1980). Canada's National Energy Program: An Analysis. Hous. J. Int'l L., 3, 155. Burns-Pieper, Annie (2014, February 21) CTV W5. Retrieved from http://www.ctvnews.ca/w5/line-9-has-had-significantly-more-spills-than-previouslystated-w5-reports-1.1698286

Girard, Richard. (2010). Out on the tar sands mainline: Mapping Enbridge's web of pipelines. The Polaris Institute, May 2010 (partially updated, March 2012).

Goldstein, B. D. (2001). The precautionary principle also applies to public health actions. American Journal of Public Health, 91(9), 1358-1361.

Goklany, I M. (2001). The precautionary principle: a critical appraisal of environment risk assessment. Washington, D.C. : CATO, c 2001. 
Hoberg, G., Rivers, A., \& Salomons, G. (2012). Comparative pipeline politics: Oil sands pipeline controversies in Canada and the United States. In Prepared for Delivery at the American Political Science Association annual meeting, New Orleans, August.

Ingram, H. M. (1973). Information channels and environmental decision making. Nat. Resources J., 13, 150.

Jones, D. P. The National Energy Board Case and the Concept of Attitudinal* Bias"(1977). McGill LJ, 23, 462.

Lucas, A. R. (1976). Legal Foundations for Public Participation in Environmental Decisionmaking. Nat. Resources J., 55, 73.

Max Paris Environmental Unit. (2013, Sep 06). Enbridge's Kalamazoo cleanup dredges up 3-year-old oil spill. CBC News. Retrieved from http://www.cbc.ca/news/politics/enbridge-s-kalamazoo-cleanup-dredges-up-3year-old-oil-spill-1.1327268

McGarity,T \& Wagner, W. (2008). Bending science: how special interests corrupt public health research. Harvard University Press, Cambridge, Mass.

Mccarthy \& Gryderman, (2014, Jun 13). Alberta insider named new head of National Energy Board, The Globe and Mail, Retrieved from http://www.theglobeandmail.com/report-on-business/alberta-insider-named-newhead-of-national-energy-board/article19166267/

McDiarmid, Jessica. (2014) First Nation seeks to appeal Line 9 pipeline approval, the First Perspective, July 09, 2014 Retrieved from http://www.firstperspective.ca/index.php/news/3074-first-nation-seeks-to-appealline-9-pipeline-approval 
Makholm, Jeff D. (2012). The Political Economy of Pipelines: A Century of Comparative Institutional Development. Retrieved from http://www.eblib.com

McGarity, T. O., \& Wagner, W. E. (2008). Bending science: How special interests corrupt public health research. Harvard University Press.

Make pipeline even safer. (2014, Mar 9). Toronto Star, p. A10 opinion. Retrieved from http://torontostar.newspaperdirect.com/epaper/viewer.aspx

Nemeth, T. L. (1997). Pat carney and the dismantling of the national energy program.

(Order No. MQ22547, University of Alberta (Canada)). ProQuest Dissertations and Theses, , 184-184 p. Retrieved from http://ezproxy.lib.ryerson.ca/ login?url=http://search.proquest.com/docview/304387483?accountid=13631. (304387483).

Nikiforuk, Andrew. (2011, June 17). National Energy Board: Captured Regulator? TheTyee.ca Retrieve from http://thetyee.ca/Opinion/2011/06/17/NEB/ NEB (National Energy Board). (2013). Canada's Energy Future 2013- Energy Supply and Demand Projections to 2035-An Energy Market Assessment. Retrieved from http://www.neb-one.gc.ca/clf-nsi/rnrgynfmtn/nrgyrprt/nrgyftr/2013/nrgftr2013eng.html

NEB. (2013, July 22). Exhibit A18-1: Letter to OPLA Ruling No.4. Retrieved from https://docs.neb-one.gc.ca/ll-eng/llisapi.dll?func=ll\&objId=976612\&objAction =browse\&viewType=1

NEB. (2013, October 08). OH-002-2013 Hearing Transcript, Volume1. Retrieved from https://docs.neb-one.gc.ca/ll-eng/llisapi.dll?func=ll\&objId= 1045208\&objAction=browse 
NEB. (2013, October 09). OH-002-2013 Hearing Transcript, Volume 2. Retrieved from https://docs.neb-one.gc.ca/ll-eng/llisapi.dll?func=ll\&objId $=1045480 \&$ objAction=browse

NEB. (2013, October 11). OH-002-2013 Hearing Transcript, Volume 4. Retrieved from https://docs.neb-one.gc.ca/ll-eng/llisapi.dll?func=ll\&objId= 1046953\&objAction=browse

NEB. (2013, October 17). OH-002-2013 Hearing Transcript, Volume6. Retrieved from https://docs.neb-one.gc.ca/lleng/llisapi.dll?func=ll\&objId=1050178\&objAction=browse

NEB. (2013, October 23). A11-5 Appendix II- List of Parties updated 23 October 2013, A3H8K3. Retrieved from https://docs.neb-one.gc.ca/lleng/lisapi.dll?func=ll\&objId=956466\&objAction=browse

NEB (National Energy Board). (2014). Reasons for Decision OH-002-2013. Retrieved from https://docs.neb-one.gc.ca/lleng/llisapi.dll?func=ll\&objId=2428616\&objAction=browse Priddle, Roland. (1999). Reflections on National Energy Board regulation 1959-98: from persuasion to prescription and on to partnership. Alberta Law Review, 07/1999, Volume 37, Issue 2, p524. ." http://en.wikipedia.org/wiki/Nemo_judex

NEB. (n.d.) Who we are. Retrieved from http://www.neb-one.gc.ca/clfnsi/rthnb/whwrndrgvrnnc/whwrndrgvrnnc-eng.html

NEB. (n.d.) Who is the National Energy Board, NEB website. Retrieved from http://www.neb-one.gc.ca/clf-nsi/rthnb/whwrndrgvrnnc/rhstry-eng.html

NEB. (n.d.). Energy Information Program-What is the National Energy Board. Retrieved from http://www.neb-one.gc.ca/clf-nsi/archives/rnrgynfmtn/ 
nrgyrprt/nrgnfrmtnprgrm/nrgnfrmtnprgrm-eng.html

NEB. (n.d.). Applying to Participate in a Hearing. NEB website. Retrieved from http://www.neb-one.gc.ca/clf-nsi/rthnb/pblcprtcptn/pblchrng/pblchrng-eng.html

NEB. (n.d.) What are the typical methods of participation in an NEB hearing. NEB website. Retrieved from http://www.neb-one.gc.ca/clfnsi/rthnb/pblcprtcptn/pblchrng/pblchrngpmphlt-eng.html\#s3_4

NEB. (n.d.) Board Members. NEB website. Retrieved from http://www.neb-one.gc.ca/clfnsi/rthnb/whwrndrgvrnnc/rgnztnndstrctr/brdmmbr/brdmmbr-eng.html

O'Riordan, T. (1976) Policy making and environmental management: some thoughts on processes and research issues. Nat. Resources J.,

Parliament. n.d. Bill C-38(historical). Open Parliament, online. Retrieved from http://openparliament.ca/bills/41-1/C-38/

Paris, M. (2013, Apr 08). NEB hearings application form called undemocratic. CBC News. Retrieved from http://www.cbc.ca/news/politics/neb-hearings-application-formcalled-undemocratic-1.1364177

Priddle, R. (1999). Reflection on National Energy Board Regulation 1959-98: From Persuasion to Prescription and on to Partnership. Alberta Law Review, 37, 524. Sager, Tore. (2013). Reviving critical planning theory: dealing with pressure, neoliberalism, and responsibility in communicative planning. Routledge.

Scott, Alison. (2014, Jan 25), Presentation to the University of Toronto International Relations Society. Retrieved from http://www.neb-one.gc.ca/clfnsi/rpblctn/spchsndprsnttn/2014/nrgymrkts/nrgymrkts-eng.html

Stein, S. \& Harper, T. (2003). Power, trust, and planning. Journal of Planning Education and 
Research, 23(2), 125-139. doi:10.1177/0739456X03258636

Stewart, Keith. (2012). Harper's Shell Game: Why Tar Sands Pipelines Are Not in Canada's National Interest. Retrieved from http://site.ebrary.com/lib/oculryerson/Doc?id=10610786\&ppg=5.

Copyright (C) 2012. Greenpeace Canada. All rights reserved.

Taylor, Brian D., Eugene J. Kim, \& John E. Gahbauer. "The Thin Red Line: A Case Study of Political Influence on Transportation Planning Practice." Journal of Planning Education and Research 29.2 (2009): 173-193.

US Environmental Protection Agency, EPA Comment Letter, April 22, 2013. Retrieved from http://www.epa.gov/compliance/nepa/keystone-xl-project-epa-comment-letter20130056.pdf

Van Hinte, T., Gunton, T. I., \& Day, J. C. (2007). Evaluation of the assessment process for major projects: a case study of oil and gas pipelines in Canada. Impact Assessment and Project Appraisal, 25(2), 123-137.

Yiftachel, O.J. Little, D. Hedgcock, and I. Alexander. 2001. The power of planning: Spaces of control and transformation. Dordrecht, the Netherlands: Kluwer Academic.

Yosie, T. F. (2001). Science-based decision making at the crossroads: Information, choices and values. Vital Speeches of the Day, 67(7), 216-219. Retrieved from http://ezproxy.lib.ryerson.ca/login?url=http://search.proquest.com/docview/ 221518099 ?accountid=13631

Younger, P. L., Coulton, R. H., \& Froggatt, E. C. (2005). The contribution of science to riskbased decision-making: Lessons from the development of full-scale treatment measures for acidic mine waters at wheal jane, UK. Science of the Total Environment, 
338(1-2), 137-154. doi:10.1016/j.scitotenv.2004.09.014

Figure References:

Figure 1 the Enbridge complex liquids pipeline systems. Enbridge, 2013, liquid Pipelines Map. Retrieved from http://www.enbridge.com/ /media/www/Site\%20Images /Illustrations/Maps/ENB_Liquids_map\%20November\%202013.pdf 